\title{
A Comparison of Data from SOLMET/ERSATZ and the National Solar Radiation Data Base
}

W. Marion and D. Myers

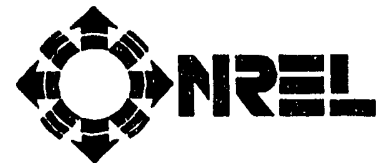

National Renewable Energy Laboratory

(formerly the Solar Energy Research Institute) 1617 Cole Boulevard Golden, Colorado 80401-3393

A Division of Midwest Research Institute Operated for the U.S. Department of Energy under Contract No. DE-AC02-83CH10093

Prepared under Task Nos. RA210101, PV360501

November 1992 


\title{
NOTICE
}

This report was prepared as an account of work sponsored by an agency of the United States government. Neither the United States government nor any agency thereof, nor any of their employees, makes any warranty, express or implied, or assumes any legal liability or responsibility for the accuracy, completeness, or usefulness of any information, apparatus, product, or process disclosed. or represents that its use would not infringe privately owned rights. Reference herein to any specific commercial product, process, or service by trade name, trademark, manufacturer, or otherwise does not necessarily constitute or imply its endorsement, recommendation, or favoring by the United States government or any agency thereof. The views and opinioris of authors expressed herein do not necessarily state or reflect those of the United States governmient or any agency thereot.

\author{
Printed in the United States of Aricrica \\ Available from: \\ National Technical Information Service \\ U.S. Department of Commerce \\ 5285 Port Royal Road \\ Springfield, VA 22161
}

Price: Microfiche A01

Printed Copy AO3

Codes are used for pricing all publications. The code is determined by the number of pages in the publication. Information pertaining to the pricing codes can be found in the current issue of the following publications which are generally available in most libraries: Energy Research Abstracts (ERA); Government Repcrts Announcements and Index (GRA and I); Scientific and Technical Abstract Reports (STAR); and publication NTIS-PR-360 available from NTIS at the above address. 


\section{Preface}

This work was performed under the National Renewable Energy Laboratory's (NREL's) Solar Radiation Research Assessment Project Task No. RA210101 and Photovoltaic Solar Radiation Research Task No. PV360501. We would like to acknowledge Dave Menicucci (Sandia), Gobind Atmaram (Florida Solar Energy Center), and NREL staff mernbers Roland Hulstrom, Carol Riordan, Dave Renné, Gene Maxwell, and Martin Rymes for their contributions to the report and their review. We would also like to thank Mary Anne Dunlap for technical editing and Terrie Webb for proofreading the appendices. 


\section{Summary}

This report compares data from the new National Solar Radiation Data Base (NSRDB) with data from the earlier SOLMET/ERSATZ data base. It compares the two data bases, station-by-station, with respect to their long-term average daily values of global horizontal and direct normal solar radiation.

We conclude that on an annual basis, NSRDB values for global horizontal radiation are within $\pm 5 \%$ of SOLMET/ERSATZ values for $60 \%$ of the stations, more than $5 \%$ greater than the SOLMET/ERSATZ values for $30 \%$ of the stations, and more than $5 \%$ less than the SOLMET/ERSATZ values for $10 \%$ of the stations. On an annual basis for direct normal radiation, the NSRDB values are within $\pm 5 \%$ of the SOLMET/ERSATZ data for only $40 \%$ of the stations, more than 5\% greater than the SOLMET/ERSATZ values for $45 \%$ of the stations, and more than $5 \%$ less than the SOLMET/ERSATZ values for $15 \%$ of the stations.

In general, the NSRDB shows higher values of solar radiation for the eastern United States, particularly the Northeast, and lower values for some of the western states (Arizona, Colorado, Idaho, Nevada, New Mexico, Utah, and Wyoming). However, because some of the stations within a state show higher values of solar radiation while others show lower values, this generalization may be misleading when concerned with a particular station. Consequently, the appendices provide tables showing a station-by-station comparison of the NSRDB and SOLMET/ERSATZ data. In addition to comparing annual values, the tables compare the two data bases for the months of August and December. This comparison shows larger differences between the two data bases for December. 


\section{Table of Contents}

$\underline{\text { Page }}$

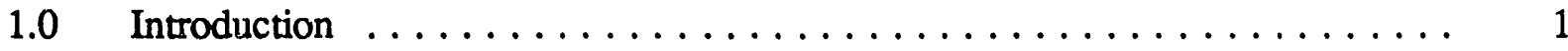

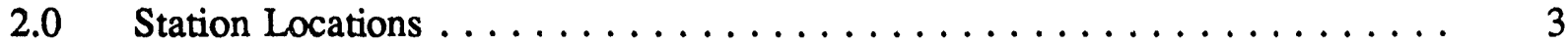

3.0 Comparison of NSRDB and SOLMET/ERSATZ Data .......... 5

3.1 Annual Solar Radiation $\ldots \ldots \ldots \ldots \ldots \ldots \ldots \ldots \ldots \ldots \ldots \ldots$

3.2 August and December Solar Radiation . . . . . . . . . . . . . 7

3.3 Daily Solar Radiation Profiles . . . . . . . . . . . . . . . . . 7

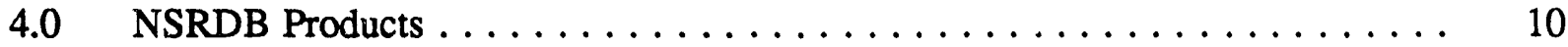

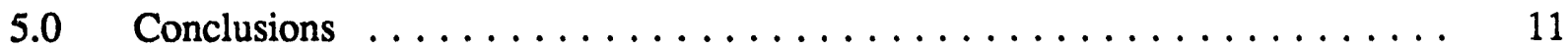

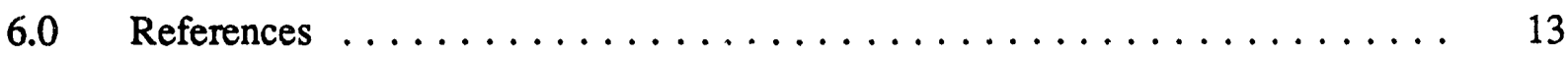

Appendix A Comparison of Annual Average Daily Radiation of SOLMET/ERSATZ and NSRDB Data Bases ............ A-1

Appendix B Comparison of Monthly Average Daily Radiation of SOLMET/ERSATZ and NSRDB Data Bases

B-1 


\section{List of Figures}

Yage

2-1 SOLMET/ERSATZ station locations $\ldots \ldots \ldots \ldots \ldots \ldots \ldots \ldots \ldots$

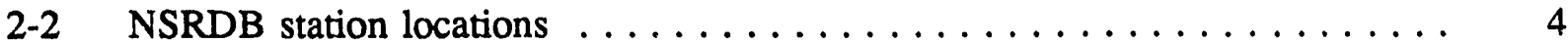

3-1 Percentage of change in profile of average global horizontal radiation in 1968 for Nashville when comparing NSRDB data to SOLMET data . . . . . . . . . . . . 8

3-2 December percentage of change in profile of average global horizontal radiation during 1961-1975 for Nashville when comparing NSRDB data to SOLMET data . . . . . . . . . . 9

5-1 Percentage of stations that have NSRDB data less than, approximately equal to, or greater than SOLMET/

\section{List of Tables}

3-1 NSRDB Solar Radiation Source Flags $\ldots \ldots \ldots \ldots \ldots$

3-2 NSRDB Solar Radiation Uncertainty Flags $\ldots \ldots \ldots \ldots \ldots \ldots$

4-1 NSRDB Solar Radiation and Meteorological Elements . . . . . . . . . . . 10

5-1 Range of Changes in Long-Term Averages When NSRDB Data Are Compared with SOLMET/ERSATZ Data . . . . . . . . . . . . .

A-1 Comparison of Annual Average Daily Radiation $\left(\mathrm{kWh} / \mathrm{m}^{2}\right)$ of

B-1 Comparison of Monthly Average Daily Radiation $\left(\mathrm{kWh} / \mathrm{m}^{2}\right)$ of SOLMET/ERSATZ and NSRDB Data Bases 


\subsection{Introduction}

The National Renewable Energy Laboratory (NREL) recently completed the National Solar Radiation Data Base (NSRDB). This new data base consists of hourly values of solar radiation and meteorological data for 239 stations for the period from 1961 to 1990 . A 30-year period of data collection was chosen to establish averages and extremes of solar radiation parameters, and it coincides with the same 30-year period used for the National Oceanic and Atmospheric Administration's (NOAA's) latest update of climate statistics. A 30-year period with updates every 10 years is a standard meteorological practice.

For the NSRDB, all of the meteorological data were provided by the National Climatic Data Center (NCDC), which is a part of NOAA. The majority of the measured solar radiation data was collected by NOAA's National Weather Service and was also provided to NREL by NCDC. Solar radiation data were also obtained from the University of Oregon; WEST Associates (a consortium of southwestern utilities); the University of New York at Albany; Trinity University, Texas; Georgia Institute of Technology; Bethune-Cookman College, Florida; and Savannah State College, Georgia (NSRDB-Vol. 1 1992).

The NSRDB is the successor to the 1952-1975 SOLMET/ERSATZ data base. In addition to accounting for the more recent climate, the NSRDB provides more accurate values of solar radiation because:

- More measured data were available during 1961 through 1990 . For the SOLMET/ERSATZ data base, there was only one measured parameter: global horizontal solar radiation at 26 stations. The new data base has measured data for 56 of the 239 stations (however, some of these stations only made measurements for a few years). For a majority of these 56 stations, two parameters were measured: global horizontal solar radiation and direct normal solar radiation. Diffuse solar radiation was also measured for several years at nine stations. The greater availability of measured data enhanced model development and testing.

- A meteorological statistical model (METSTAT) provided better estimates of solar radiation for sites and times where no measurements were available (Maxwell 1991). Because $93 \%$ of the solar radiation data in the NSRDB is modeled, much emphasis was placed on model development.

- The accuracy of the measured data is improved. From 1977 to 1990 , a radiometer calibration facility, operated by NOAA in Boulder, Colorado, performed routine calibrations to ensure the accuracy of instruments used to measure solar radiation by the National Weather Service. Universities and other agencies that provided solar radiation data also performed routine instrument calibrations.

- An improved synthetic calibration procedure (SYNCAL) corrected global horizontal solar radiation data for solar zenith and azimuth angles. Calibration corrections were determined for $10^{\circ}$ by $20^{\circ}$ zenith angle-azimuth angle cells for each instrument. The corrections were largest for data collected prior to 1976 , when measurements were made using older style pyranometers.

- Procedures and software were devised for performing postmeasurement quality assessment of data. Each solar radiation data value was assigned a quality flag consisting of two characters that provide information on the source and uncertainty of the data. 
The NSRDB represents the more recent climate and has an improved accuracy, but designers and engineers might ask the questions: Compared with SOLMET/ERSATZ data, how will NSRDB data impact analysis and design? Have the averages and extremes for the stations changed? Will we estimate more energy produced or less? Will the collector be sized larger or smaller?

Although this report does not answer these questions for specific applications, it does provide initial insight by comparing the two data bases with respect to their loing-term averages of global horizontal and direct normal solar radiation on a station-by-station bas: $\because$ The objective is to inform potential users about the magnitude of the differences between the two data bases for long-term averages of global horizontal and direct normal solar radiation.

Also, the information presented in this report is not intended for energy analysis and system design purposes. Analysis and design information will result from FY 1993 activities of NREL's Solar Radiation Research Assessment Project. The FY 1993 work includes using the data for the 239 NSRDB stations to develop typical meteorological year (TMY) data sets and to generate tabular data giving information on the monthly averages of solar radiation, the extremes, and the variability for various fixed and tracking collectors. FY1993 work will also include a detailed analysis explaining the reasons for the differences between the two data bases shown in this report. The contribution of improved measurements and models and the effects of climate change, such as changes in the amount of cloud cover, will be evaluated and presented.

This report begins by identifying the station locations for the two data bases. Next, annual and monthly long-term averages for global horizontal and direct normal solar radiation are compared, and daily solar radiation profiles are discussed. Last, information is provided on the NSRDB and its derived products, and the results are summarized. 


\subsection{Station Locations}

The 248 station locations in the SOLMET/ERSATZ data base are shown in Figure 2-1. These stations were operated by the National Weather Service of NOAA. Data from 1952 to 1975 were included in this data base. Hourly values of givial horizontal radiation were measured at 26 SOLMET stations during this period, and researchers modeled hourly values of direct normal radiation for these stations. In Figure 2-1, the SOLMET stations are identified by the use of the asterisk (*) symbol. No solar radiation measurements were made at the 222 ERSATZ stations. Rather, global horizontal radiation was modeled based on observed meteorological data such as cloudiness and minutes of sunshine. The ERSATZ data do not include direct normal radiation data, but this information is available in data sets derived from the ERSATZ data, such as ERSATZ TMY data sets and tabular data sets (SERI 1990) that modeled direct normal radiation for most of the ERSATZ sites.

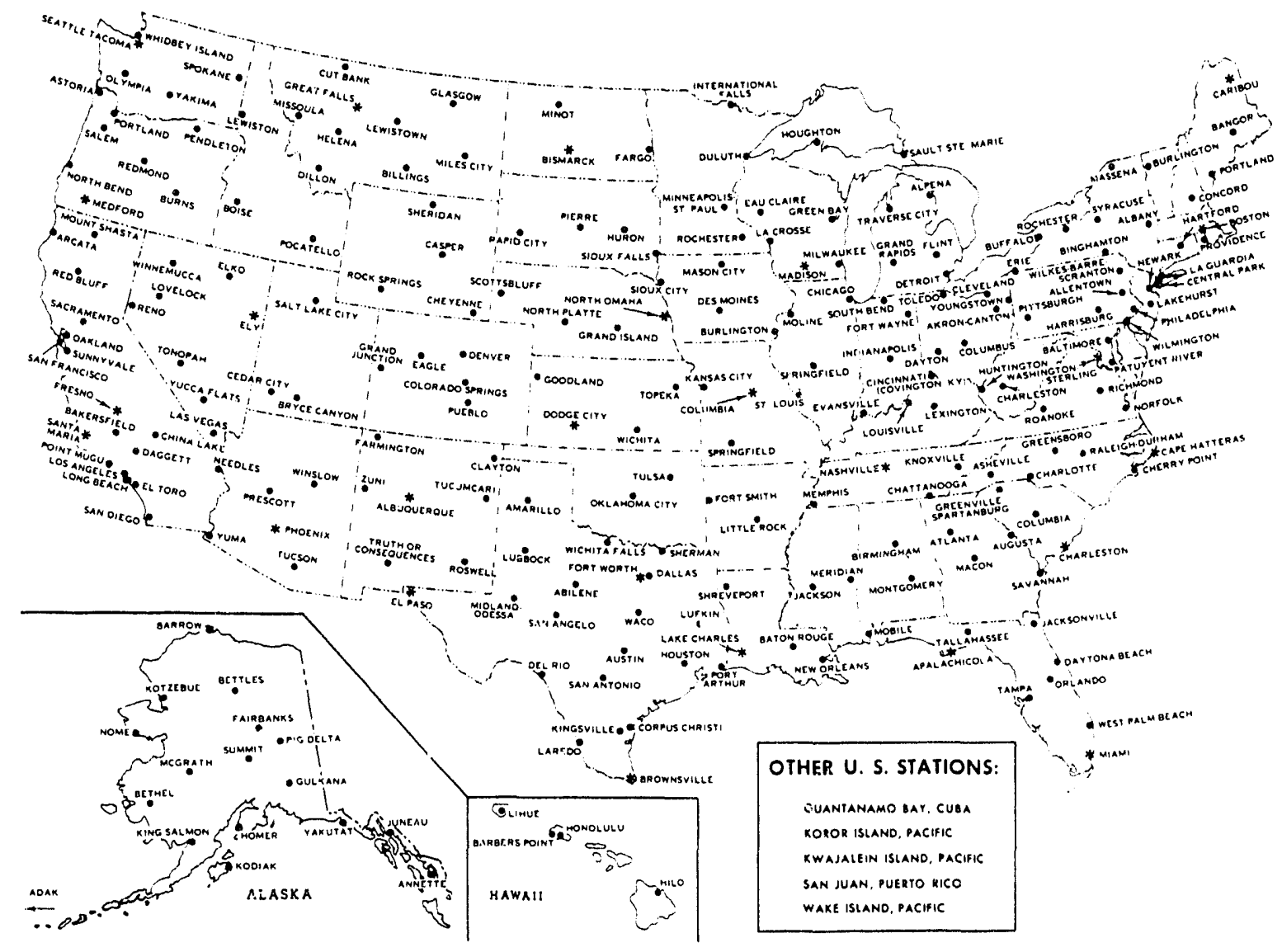

Figure 2-1. SOLMET/ERSATZ station locations 
The 239 station locations in the NSRDB are shown in Figure 2-2. Because of the criteria for selecting stations, there are nine fewer stations than for the SOLMET/ERSATZ data base. Stations were selected only if they were National Weather Service stations that had meteorological data for the entire period from 1961 to 1990 . The meteorological data were used to model solar radiation for times and locations where it was not measured. Measured solar radiation data in the NSRDB provided by universities and other agencies were incorporated by assigning them to the nearest NSRDB station. Although most of the stations in the NSRDB and the SOLMET/ERSATZ data base are the same, the selection criteria for the NSRDB caused some states to gain stations while other states lost stations. The NSRDB includes 37 new stations, but 46 previous SOLMET/ERSATZ stations were not included.

For the NSRDB, the 56 stations that measured solar radiation data, for at least a part if not the entire 30 years, are designated primary stations. The remaining 183 stations that have only modeled solar radiation data are designated secondary stations. The word secondary was deemed preferable to the word ersatz, which means an inferior substitute.

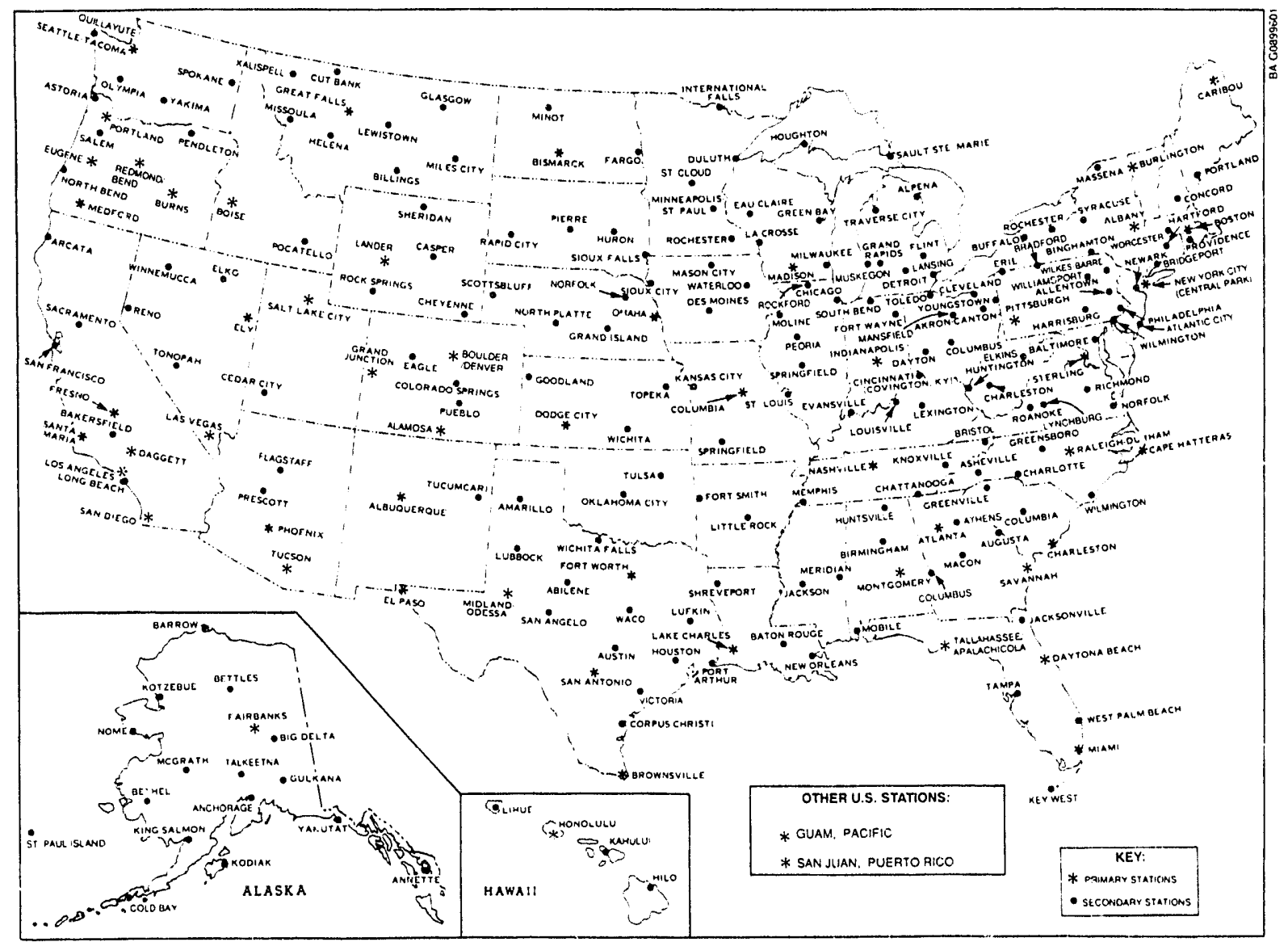

Figure 2-2. NSRDB station locations 


\subsection{Comparison of NSRDB and SOLMET/ERSATZ Data}

Long-term averages of global horizontal and direct normal solar radiation for each of the two data bases were compared on an annual basis and for the months of August and December. For the comparison, the long-term averages of solar radiation used for the NSRDB stations were those presented in the daily statistic files for each station. Daily statistic files are one of the NSRDB products (NSRDB-Vol. 1 1992). For the SOLMET/ERSATZ long-term averages, tabular data were taken from the Insolation Data Manual and Direct Normal Solar Radiation Data Manual, (SERI 1990). Differences in long-term averages for the two data bases are due to differences in the measurement instruments, solar radiation models, and time periods. The SOLMET/ERSATZ data base spans 23-1/2 years, from 1952 to 1975, and the NSRDB spans 30 years, from 1961 to 1990.

\subsection{Annual Solar Radiation}

Appendix A contains tables that compare the average annual global horizontal and direct normal solar radiation of the two data bases. All 239 NSRDB stations are listed in the tables along with their Weather Bureau Army Navy (WBAN) number and other station identification information such as latitude, longitude, and elevation. The SOLMET/ERSATZ stations not in the NSRDB (46 total) are not listed in the tables. SOLMET stations are identified in the tables by the use of the asterisk (*) symbol, and the pound (\#) symbol is used to identify NSRDB primary stations. The absence of a station identifying symbol means the station is an ERSATZ station and/or a NSRDB secondary station.

Although not available for the SOLMET/ERSATZ data, quality flags accompany the NSRDB data in the tables. The quality flags consist of two characters and provide information on the source and uncertainty of the NSRDB data. The solar radiation source and uncertainty flags are defined in Tables 3-1 and 3-2 (NSRDB-Vol. 1 1992). Most of the NSRDB data listed in the tables in Appendix A are assigned an uncertainty flag of 4 , meaning the uncertainty of the data is from $6 \%$ to $9 \%$ of the solar radiation value.

The percentage of change listed in the tables indicates the percentage increase or decrease in solar radiation when comparing NSRDB and SOLMET/ERSATZ data. A value greater than zero means that the NSRDB data are greater than the SOLMET/ERSATZ data; a value below zero means the reverse is true. For NSRDB stations that have no corresponding SOLMET/ERSATZ station, no percintage change is indicated. Also, some ERSATZ stations have no direct normal radiation data; ccnseguently, a comparison cannot be made for this situation either.

For global horizontal radiation, the NSRDB values are within $\pm 5 \%$ of the SOLMET/ERSATZ values for $60 \%$ of the stations, more than $5 \%$ greater than the SOLMET/ERSATZ yalues for $30 \%$ of the stations, and more than 5\% less than the SOLMET/ERSATZ values for $10 \%$ of the stations. For direct normal radiation, the NSRDB values are within $\pm 5 \%$ of the SOLMET/ERSATZ values for only $40 \%$ of the stations, more than $5 \%$ greater than the SOLMET/ERSATZ values for $45 \%$ of the stations, and more than $5 \%$ less than the SOLMET/ERSATZ values for $15 \%$ of the stations.

In general, the NSRDB data show higher values for solar radiation for the eastern United States, particularly the northeast, and lower values for some of the western states ( Arizona, Coloradu, Idaho, Nevada, New Mexico, Utah, and Wyoming). Examples of much higher values are stations in New York that show increases in global horizontal radiation of up to $17 \%$ and increases in direct normal radiation of up to $24 \%$. Portland, Maine, shows the largest increase for a single station, $18 \%$ for global horizontal and $33 \%$ for direct normal. Nevada stations show 
Table 3-1. NSRDB Solar Radiation Sourco Flags

\begin{tabular}{|c|c|}
\hline Flag & Definition \\
\hline A & $\begin{array}{l}\text { Post- } 1976 \text { measured solar radiation data as received from NCDC or } \\
\text { other sources }\end{array}$ \\
\hline B & $\begin{array}{l}\text { Same as ' } A \text { ' except the global horizontal data underwent a calibration } \\
\text { correction }\end{array}$ \\
\hline $\mathrm{C}$ & $\begin{array}{l}\text { Pre-1976 measured global horizontal data (direct and diffuse were not } \\
\text { measured before 1976) }\end{array}$ \\
\hline $\mathrm{D}$ & $\begin{array}{l}\text { Data derived from the other two elements of solar radiation using the } \\
\text { relation: } \mathrm{Kt}=\mathrm{Kn}+\mathrm{Kd} \text {, where } \mathrm{Kt}=\text { global horizontal transmidance, } \\
\mathrm{Kn}=\text { direct normal transmittance, and } \mathrm{Kd}=\text { diffuse horizontal } \\
\text { ransmittance. }\end{array}$ \\
\hline $\mathrm{E}$ & $\begin{array}{l}\text { Modeled solar radiation data using inputs of observed sky cover } \\
\text { (cloud amount) and aerosol optical depths derived from direct normal } \\
\text { data collected at the same location }\end{array}$ \\
\hline $\mathrm{F}$ & $\begin{array}{l}\text { Modeled solar radiation data using inputs of interpolated sky cover } \\
\text { and aerosol optical depths derived from direct normal data collected } \\
\text { at the same location }\end{array}$ \\
\hline G & $\begin{array}{l}\text { Modeled solar radiation data using observed sky cover and aerosol } \\
\text { optical depths estimated irom geographical relationships }\end{array}$ \\
\hline $\mathrm{H}$ & $\begin{array}{l}\text { Modeled solar radiation data using interpolated sky cover and } \\
\text { estimated aerosol optical depths }\end{array}$ \\
\hline$?$ & $\begin{array}{l}\text { Source does not fit any of the above categories. Used for nighttime } \\
\text { values, calculated extraterrestrial values, and missing da:a }\end{array}$ \\
\hline
\end{tabular}

Table 3-2. NSRDB Solar Radiation Uncertainty Flags

\begin{tabular}{|c|c|}
\hline Flag & Uncertainty Range (\%) \\
\hline 1 & $0-2$ \\
2 & $2-4$ \\
3 & $4-6$ \\
4 & $6-9$ \\
5 & $9-13$ \\
6 & $13-18$ \\
7 & $18-25$ \\
8 & $25-35$ \\
9 & $35-50$ \\
0 & Not applicable \\
\hline
\end{tabular}


the largest decreases, from $-4 \%$ to $-10 \%$ for global horizontal radiation, and from $-5 \%$ to $-24 \%$ for direct normal radiation. Within a state, some of the stations may show higher values for solar radiation while others show lower values; consequently, generalizations about a change in solar radiation for a state may prove inaccurate. The tables in Appendix A may be used to evaluate changes for each station within a state.

\subsection{August and December Solar Radiation}

Appendix B contains tables that compare the average global horizontal and direct norrial solar radiation of the two data bases for two months of the year, August and December. These two moths were chosen because they have special significance for solar energy systems. For many stand-alone PV systems, designers siz: the PV system based on the amount of solar radiation for the month of December (assuming that December is $t^{\top} 1 e$ month with the smallest ratio of solar-radiation-to-electric-load demand). Therefore, a change in the solar resource for December can impact system size and cost. August was chosen because utilities analyze whether or not a solar electric power plant can help meet summertime electric demand. Consequently, a change in the solar resource for the month of August could favorably or unfavorably change the results of their analysis. The tables in Appendix B are similar to those in Appendix A, except they do not include the station identification information and the source and uncertainty flags for the NSRDB data. The tables in Appendix A provide this information.

For global horizontal radiation for August, the NSRDB values are within $\pm 5 \%$ of the SOLMET/ERSATZ values for $70 \%$ of the stations, more than $5 \%$ greater than the SOLMET/ERSATZ values for $20 \%$ of the stations, and more than $5 \%$ less than the SOLMET/ERSATZ values for $10 \%$ of the stations. For direct normal radiation for August, the NSRDB values are within $\pm 5 \%$ of the SOLMET/ERSATZ values for $55 \%$ of the stations, more than $5 \%$ greater than the SOLMET/ERSATZ values for $20 \%$ of the stations, and more than $5 \%$ less than the SOLMET/ERSATZ values for $25 \%$ of the stations. Overall, the results of the comparison for August were similar to the results of the annual comparison, but not necessarily with respect to individual stations.

For global horizontal radiation for December, the NSRDB values are within $\pm 5 \%$ of the SOLMET/ERSATZ values for $25 \%$ of the stations, more than $5 \%$ greater than the SOLMET/ERSATZ values for $70 \%$ of the stations, and more than $5 \%$ less than the SOLMET/ERSATZ values for 5\% of the stations. For direct normal radiation for December, the NSRDB values are within $\pm 5 \%$ of the SOLMET/ERSATZ values for $30 \%$ of the stations, more than 5\% greater than the SOLMET/ERSATZ values for $50 \%$ of the stations, and more than $5 \%$ less than the SOLMET/ERSATZ values for $20 \%$ of the stations. December shows larger differences between the two data bases than does the annual or August comparison. Changes in global horizontal radiation ranged from $-8 \%$ to $+51 \%$, and changes in direct normal radiation ranged from $-32 \%$ to $+56 \%$ (not including Alaskan stations where small values yielded larger percentage changes).

\subsection{Daily Solar Radiation Profiles}

For solar energy systems that have desired output requirements for specific times of the day, knowing how the solar radiation varies throughout the day fermiti evaluating different design options with respect to their load-matching ability. The daily solar radiation profile also influences the optimum orientation of fixed-tilt collectors and the performance benefit of tracking collectors when compared with fixed-tilt collectors. Evaluating the daily solar radiation profiles for each station is beyond the scope of this report, but the comparison and discussion for a single station can, as a minimum, demonstrate and provide insight into how SOLMET/ERSATZ and NSRDB daily solar radiation profiles may differ. 


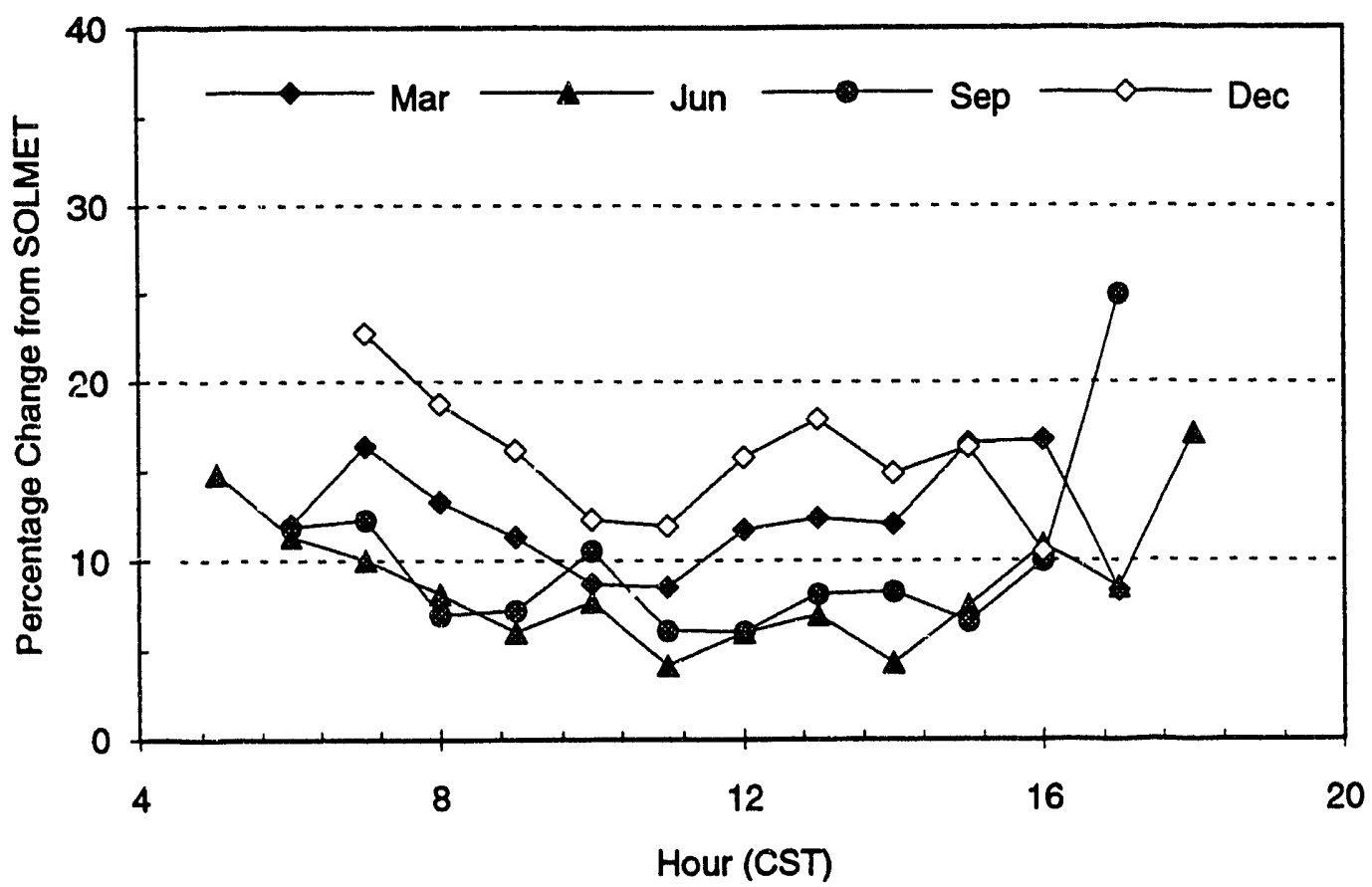

Figure 3-1. Percentage of change in profile of average global horizontal radiation in 1968 for Nashville when comparing NSRDB data to SOLMET data

Figure 3-1 compares the average daily profile for different months of the year for global horizontal radiation measured during 1968 at Nashville, Tennessee. For clarity, four months of the year are shown that represent different seasons and sun positions. For this station and year, the NSRDB data show an increase for all months when compared with the SOLMET data. Because both the SOLMET and NSRDB data are based on the same raw data measuremints (1968 is a common year for both data bases), the difference between the two data bases results from using different synthetic calibration procedures. For NSRDB data, the synthetic calibration procedure also included correcting for solar zenith and azimuth angle. Each instrument was characterized for cosine and azimuth angle response, and then correction factors were applied to the data. The effect of this correction, shown in Figure 3-1, resulted in a greater difference between the SOLMET and NSRDB data for early morning and late afternoon hours and for the month of December. These times correspond to larger solar zenith angles that required larger correction factors to account for the imperfect cosine response of the instrument.

Corrections of NSRDB data were dependent on the zenith and azimuth angle response of the station's pyranometer. Each pyranometer had distinct characteristics. Some showed solar zenith and azimuth angle responses requiring different corrections for morning and afternoon and months of the year. Consequently, different corrections were required for all stations. In addition, when pyranometers were replaced at individual stations, different correction factors were applied to match the instrument being used. This is shown in Figure 3-2 in which the average daily profiles of global horizontal radiation from 1961 to 1975 for December at Nashville are illusirated. Notice how the different synthetic calibration procedures for the NSRDB caused the daily profiles to change from year to year when compared with the SOLMET profiles. Changes due to replacing instruments are also evident. (The profiles in Figure 3-2 are plotted against the hour of day, not the year, as indicated by the $\mathrm{X}$-axis. The profile for December 1968 is the same as the December 1968 profile shown in Figure 3-1, but different scales are used.) 


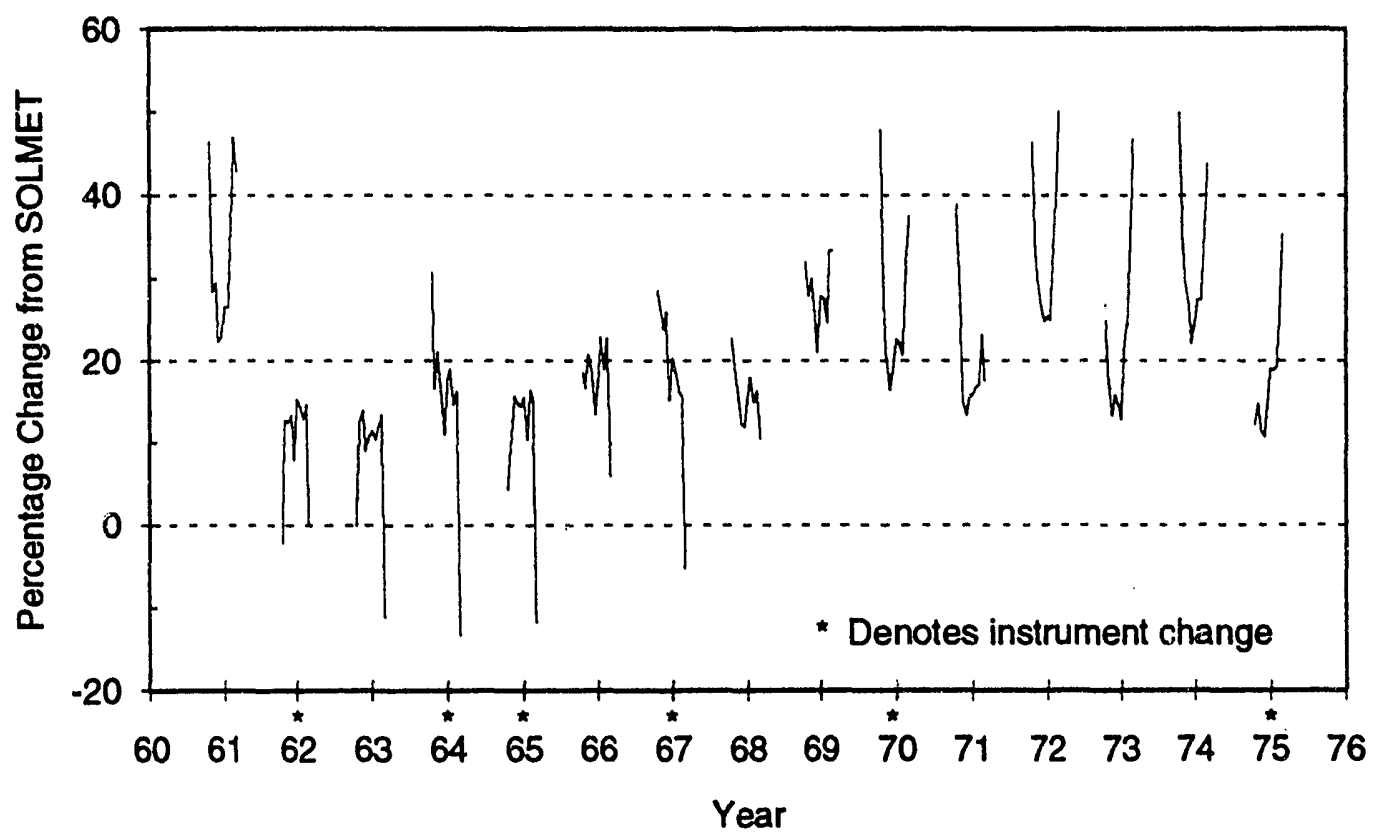

Figure 3-2. December percentage of change in profile of average global horizontal radiation during 1961-1975 for Nashville when comparing NSRDB data to SOLMET data

Aithough daily profiles were not evaluated for each station, the daily profiles for the NSRDB can be expected to be different than those for the SOLMET/ERSATZ data base. Therefore, analyses performed concerning such things as load matching, optimum azimuth orientation of fixed collectors, and benefits of tracking collectors would be affected.

For NSRDB secondary stations and partly cloudy skies, the individual hourly model estimates can be different from the actual solar radiation received. Input parameters to the METSTAT model describe only the percentage of the sky dome covered by clouds and not the position of the clouds with respect to the sun. Consequently, for the same amount of cloud cover, the actual solar radiation can vary a large amount depending on the time during the hour that clouds are actually positioned in front of the sun. But for monthly and annual data, which have numerous hourly data values, the METSTAT model successfully simulates their statistical and stochastic characteristics (NSRDB-Vol. 1 1992). 


\subsection{NSRDB Products}

Products available from the NSRDB include (1) serial hourly data in either a synoptic or TD3282 format, (2) hourly, daily, and quality statistics for solar radiation elements, (3) daily statistics for meteorological elements, and (4) persistence statistics for daily total solar radiation.

The synoptic format is similar to the SOLMET format. Each line of data contains all solar radiation and meteorological elements for 1 hour. The next line of data contains data for the next hour. The synoptic format includes quality flags for global horizontal, direct normal, and diffuse horizontal radiation. Table 4-1 lists the solar radiation and meteorological data available in both the synoptic and TD-3282 format.

For the TD-32:2 format, each line of data contains a day (24 hourly values) of data for one element. The next line of data contains a day of data for the next element. This format offers flexibility because only the solar radiation and meteorological elements requested need to be included in the data file. The TD-3282 fornat includes quality flags for all elements.

Both the synoptic and TD-3282 formats use local civil time for the hour of the day. For most applications, this is more useful than the solar time used for the SOLMET/ERSATZ data. When using the new NSRDB data to evaluate the performance of a solar energy system, analysis software and programs need to make the distinction between local civil time and solar time. Otherwise, the sun position and the amount of solar radiation for the collector will not be correctly calculated.

Statistical summaries computed from the hourly data include hourly, monthly, annual, and 30year averages and their standard deviations. The statistical products, as well as the synoptic and TD-3282 formats, are ccmpletely described in the user's manual (NSRDB-Vol. 1 1992) available from the National Climitic Data Center (NCDC). The NSRDB data and statistical products may also be ordered from NCDC. Please use the following address for correspondence:

User Services

National Climatic Data Center

Federal Building

Asheville, NC 28801-2696

Phone (704)259-0682

Fax (704)259-0876

Table 4-1. NSRDB Solar Radiation and Meteorological Elements

\begin{tabular}{|l|l|}
\hline Global horizontal radiation & Atmospheric pressure \\
Direct normal radiation & Wind direction \\
Diffuse horizontal radiation & Wind speed \\
Extraterrestrial radiation & Horizontal visibility \\
Direct normal extraterrestrial radiation & Ceiling height \\
Total sky cover & Present weather \\
Opaque sky cover & Total precipitable water \\
Dry-bulb temperature & Aerosol optical depth \\
Dew-point temperature & Snow depth \\
Relative humidity & Number of days since last snowfall \\
\hline
\end{tabular}




\subsection{Conclusions}

The NSRDB is the successor to the SOLMET/ERSATZ data base. Its data better represents the solar resource because improved equipment measured solar radiation at more sites and better models estimated solar radiation for sites and times where no measurements were available. By comparing the two data bases with respect to their long-term averages of global horizontal and direct normal radiation, differences between the two data bases are evident. Appendices $A$ and $B$ present the results of this comparison, station-by-station, for annual and monthly (August and December) values of solar radiation.

Even though the two data bases compare within $\pm 5 \%$ for many stations, the NSRDB data for others show changes in annual global horizontal radiation frum $-10 \%$ to $+18 \%$ and changes in annual direct normal radiation from $-24 \%$ to $+33 \%$. For the two months compared, the percentage of change was greater for December than for August. For December, the NSRDB data show changes in global horizontal radiation from $-8 \%$ to $+51 \%$ and show changes in direct normal radiation from $-32 \%$ to $+56 \%$ (not including Alaskan stations). Figure 5-1 and Table 5-1 present summary information on the comparisons made using SOLMET/ERSATZ and NSRDB data.

Because of the differences in solar radiation values for the two data bases, the performance and econornic analyses performed for some stations will show large changes when NSRDB data are used instead of SOLMET/ERSATZ data. For all stations, the credibility of performance and economic analyses is increased because the methods used during the development of the NSRDB had the advantage of more high quality measured data for developing better models (Maxwell et al.1991).

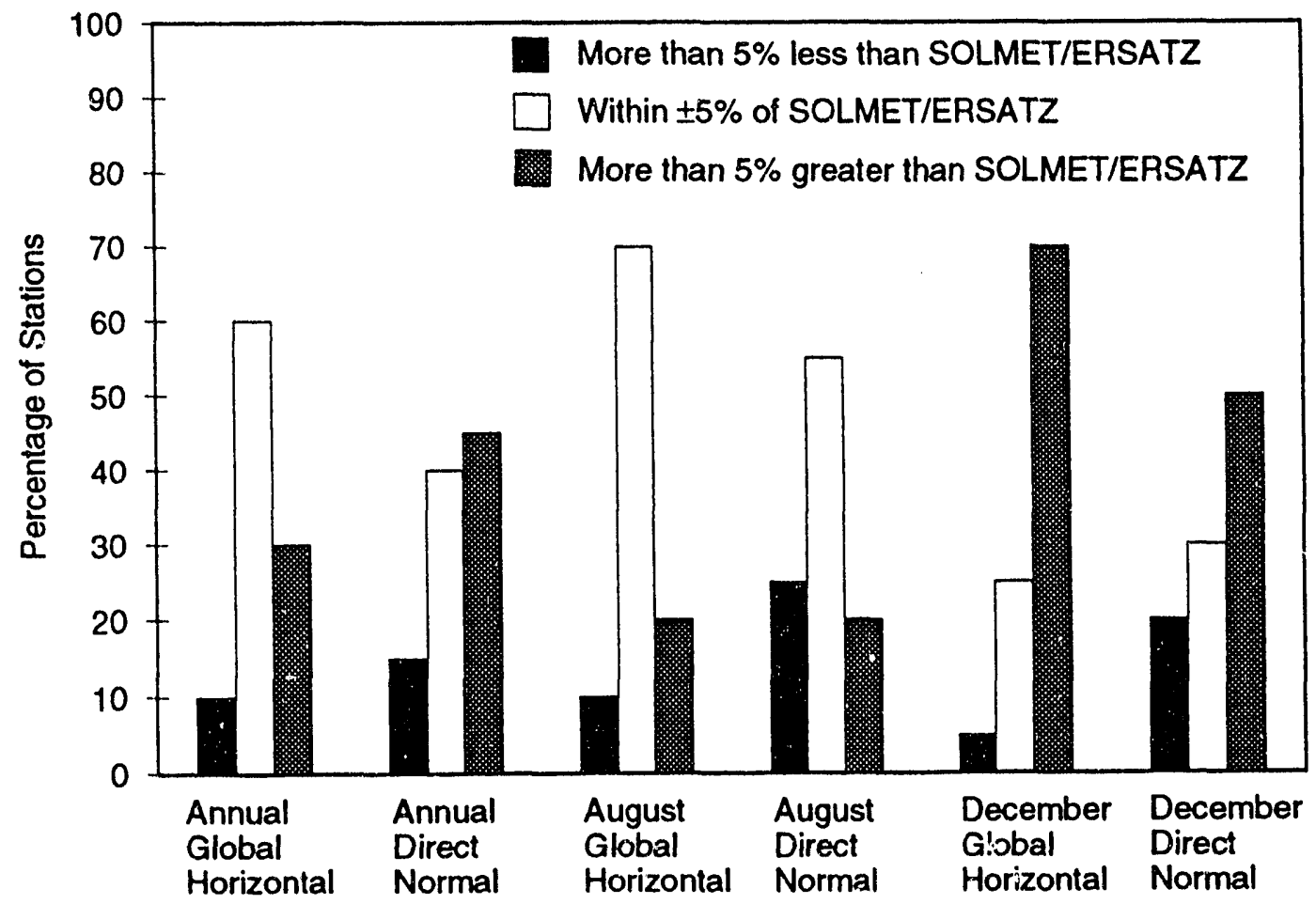

Figure 5-1. Percentage of stations that have NSRDB data less than, approximately equal to, or greater than SOLMET/ERSATZ data 
Table 5-1. Range of Changes in Long-Term Averages When NSRDB Data Are Compared with SOLMET/ERSATZ Data

\begin{tabular}{|l|c|c|}
\hline Period & Global Horizontal & Direct Normal \\
\hline Annual & $-10 \%$ to $+18 \%$ & $-24 \%$ to $+33 \%$ \\
August & $-11 \%$ to $+16 \%$ & $-20 \%$ to $+31 \%$ \\
December & $-8 \%$ to $+51 \%$ & $-32 \%$ to $+56 \%$ \\
\hline
\end{tabular}

Future work includes developing products from the NSRDB such as TMY data sets and tabular data for various fixed and tracking collectors. A detailed analysis explaining the reasons for differences between SOLMET/ERSATZ and NSRDB data is also under way. We also encourage others to evaluate the NSRDB. Of particular interest is how modeled solar radiation data for NSRDB secondary stations compare with measured data from nearby solar radiation monitoring stations operated by independent organizations and regional networks. 


\subsection{References}

Maxwell, E.L. (1991). "Simulating Solar Radiation Data Sets." Proceedings of the Biennial Congress of the International Solar Energy Society; August 19-23, 1991, Denver, Colorado, pp. 975-980.

Maxwell, E.L.; Myers, D.R.; Rymes, M.D.; Stoffel, T.L.; Wilcox, S.M. (1991). "Producing a National Solar Radiation Data Base." Proceedings of the Biennial Congress of the International Solar Energy Society; August 19-23, 1991, Denver, Colorado, pp. 10071012.

NSRDB-Vol. 1 (1992). User's Manual - National Solar Radiation Data Base (1961-1990). Version 1.0. Asheville, NC: National Climatic Data Center.

SERI (1990). Insolation Data Manual and Direct Normal Solar Radiation Data Manual, SERI/TP-220-3880, Golden, CO: Solar Energy Research Institute. 
Appendix A

Comparison of Annual Average Daily Radiation of SOLMET/ERSATZ and NSRDB Data BaseS 


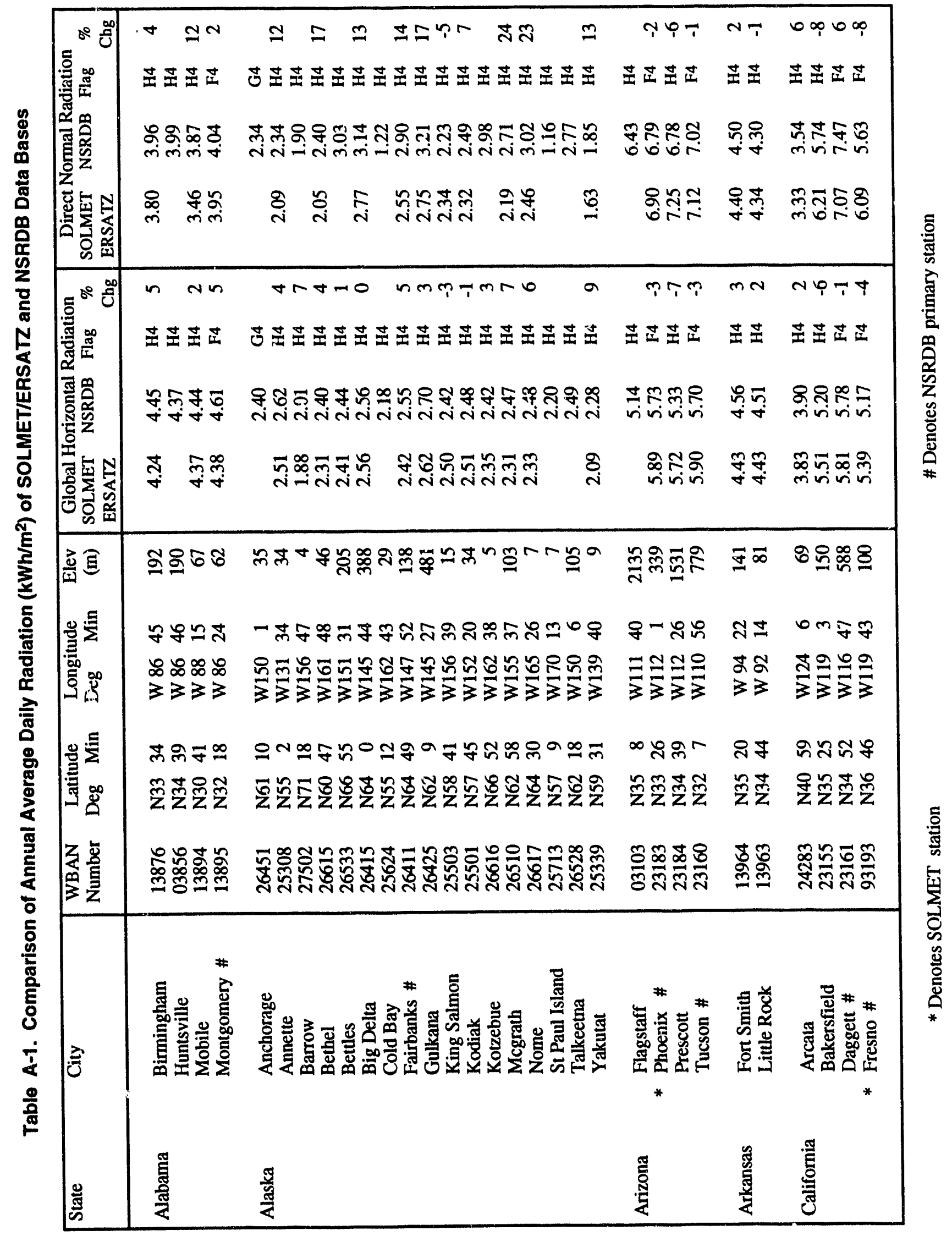




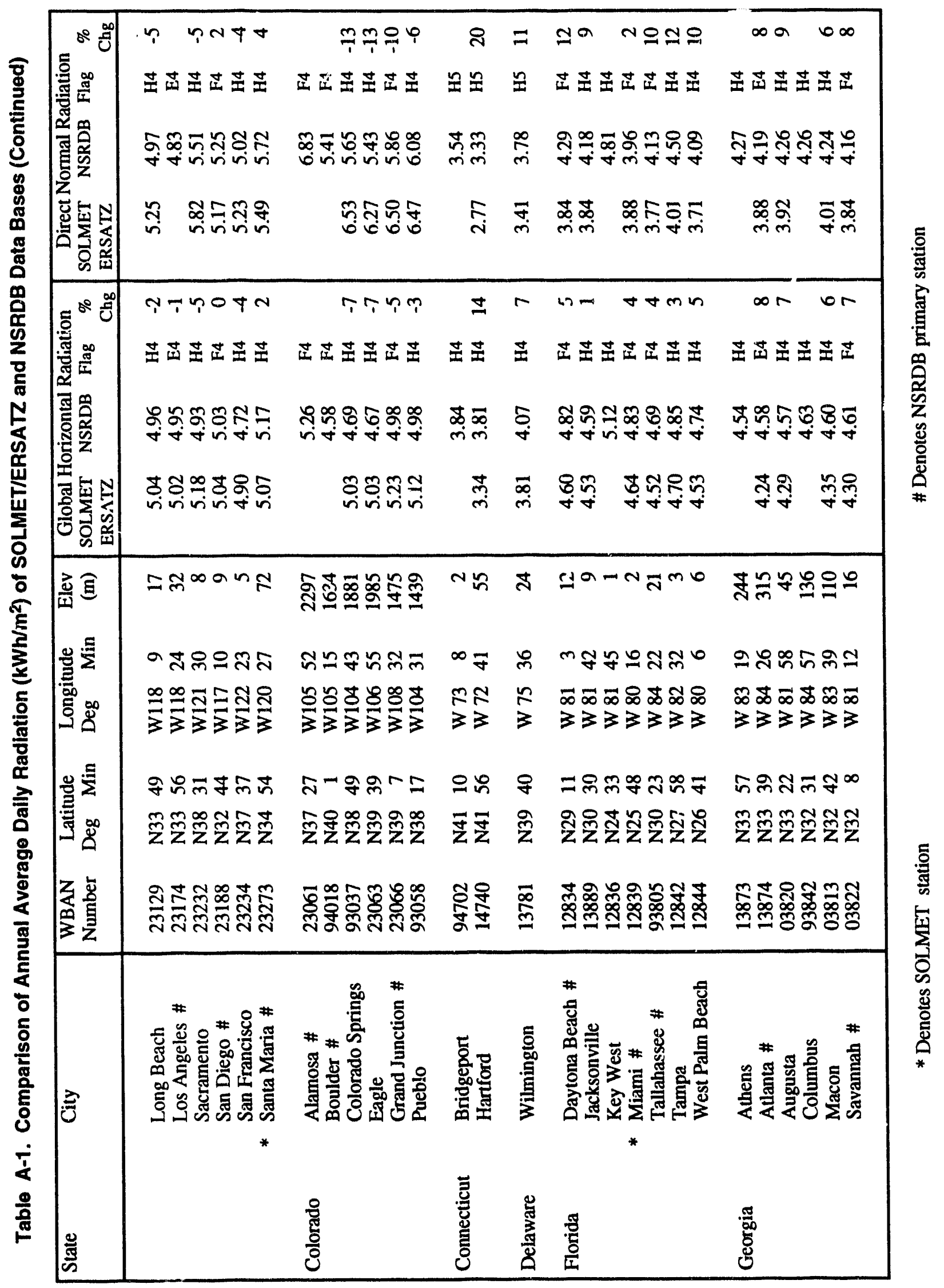




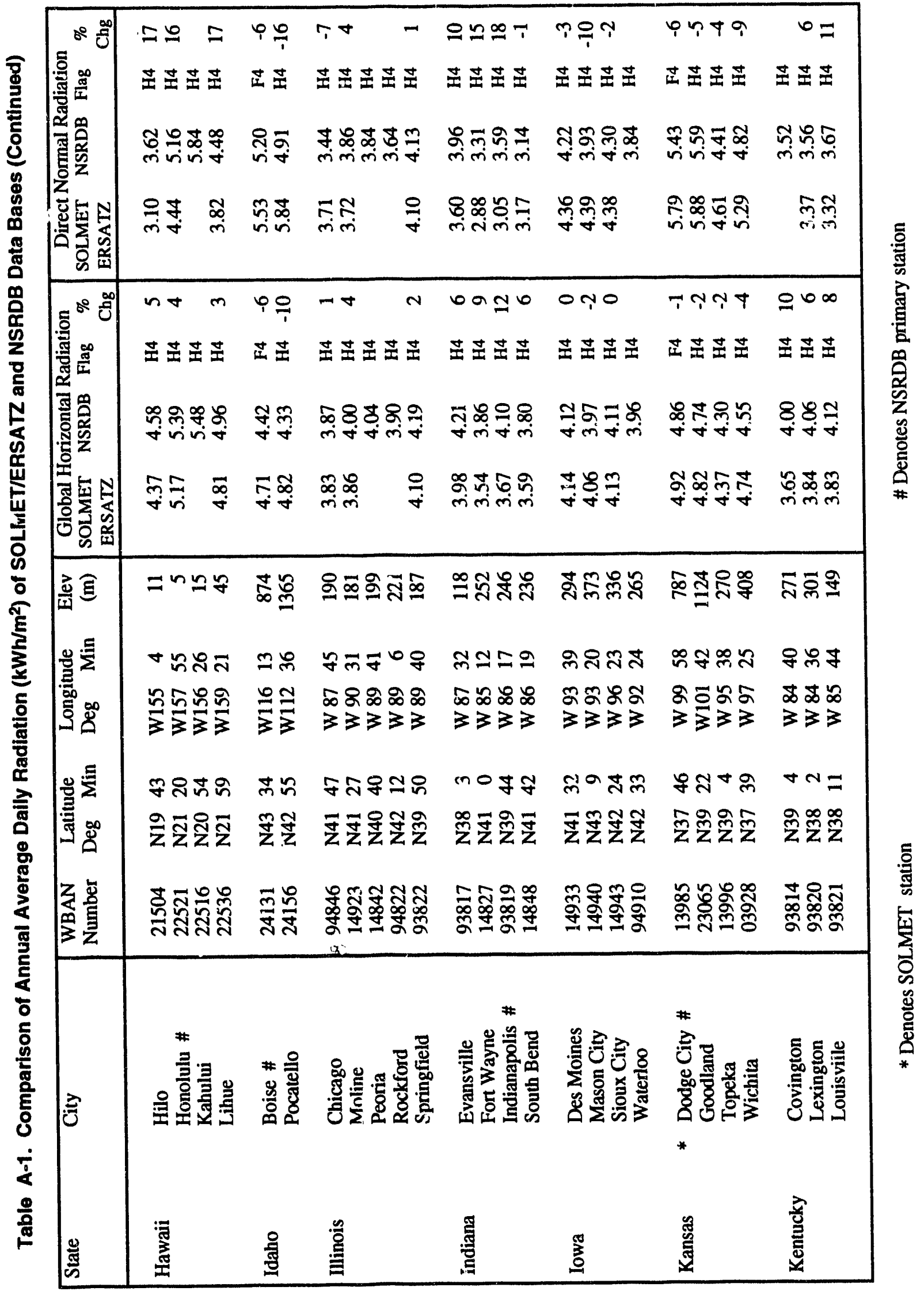




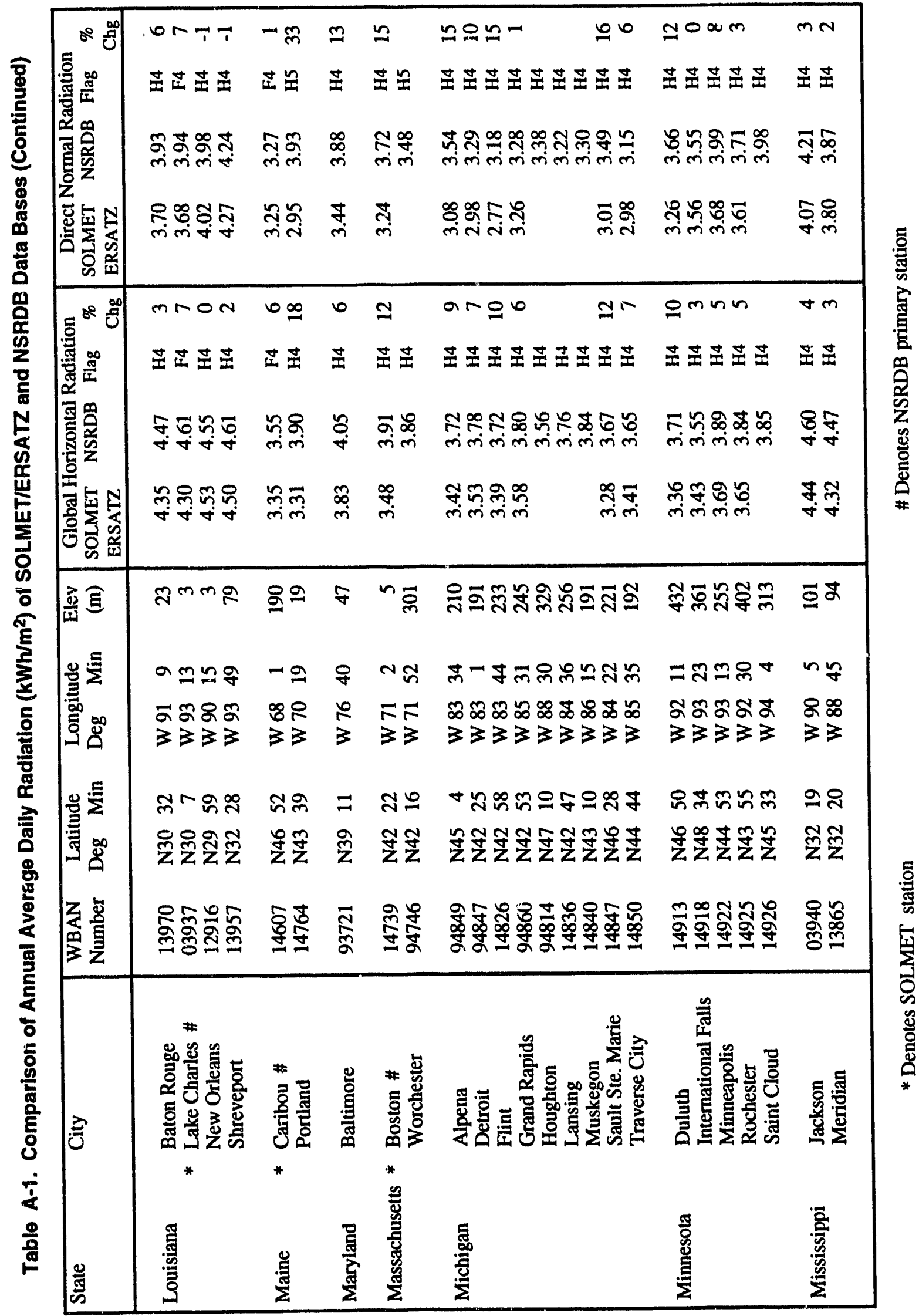




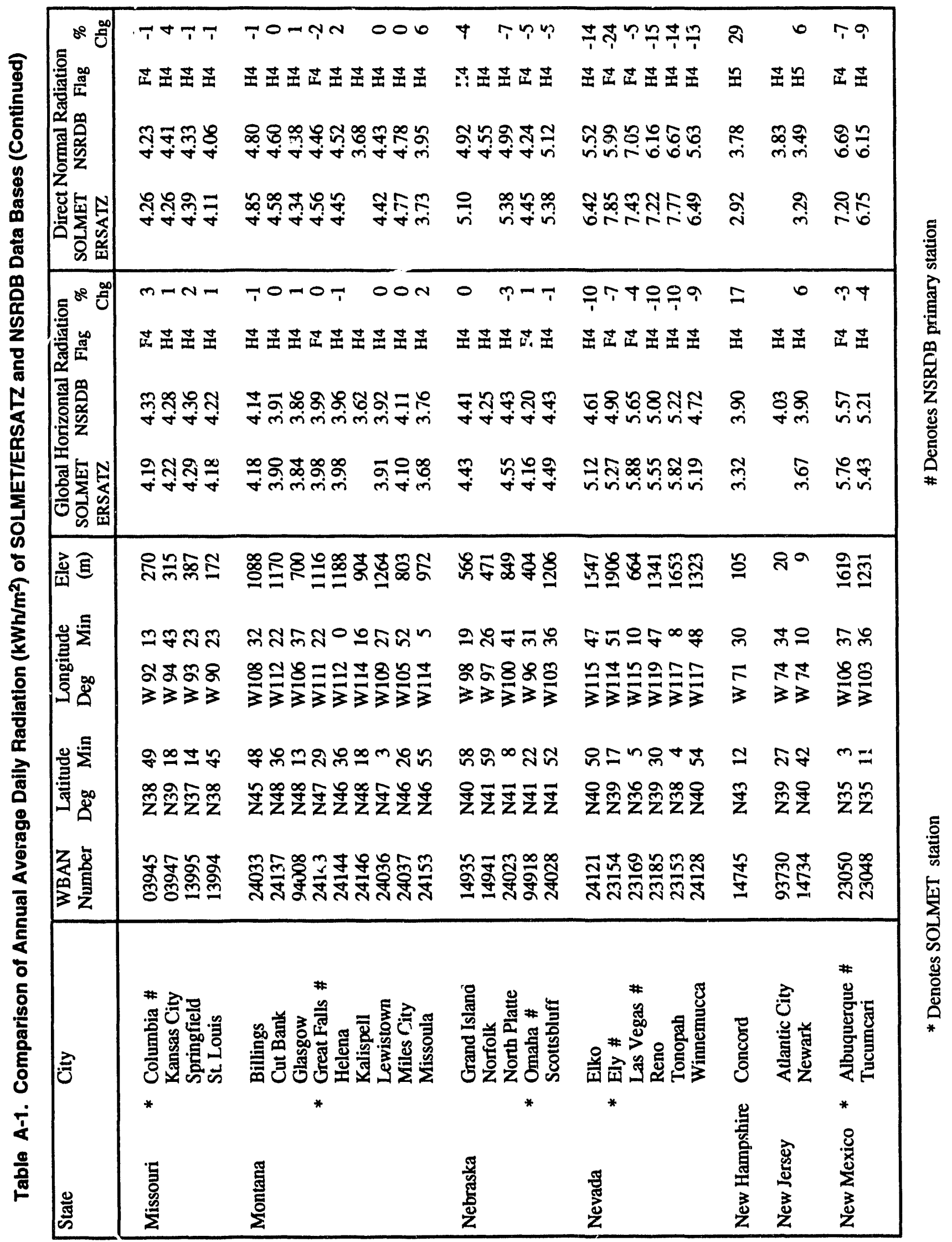




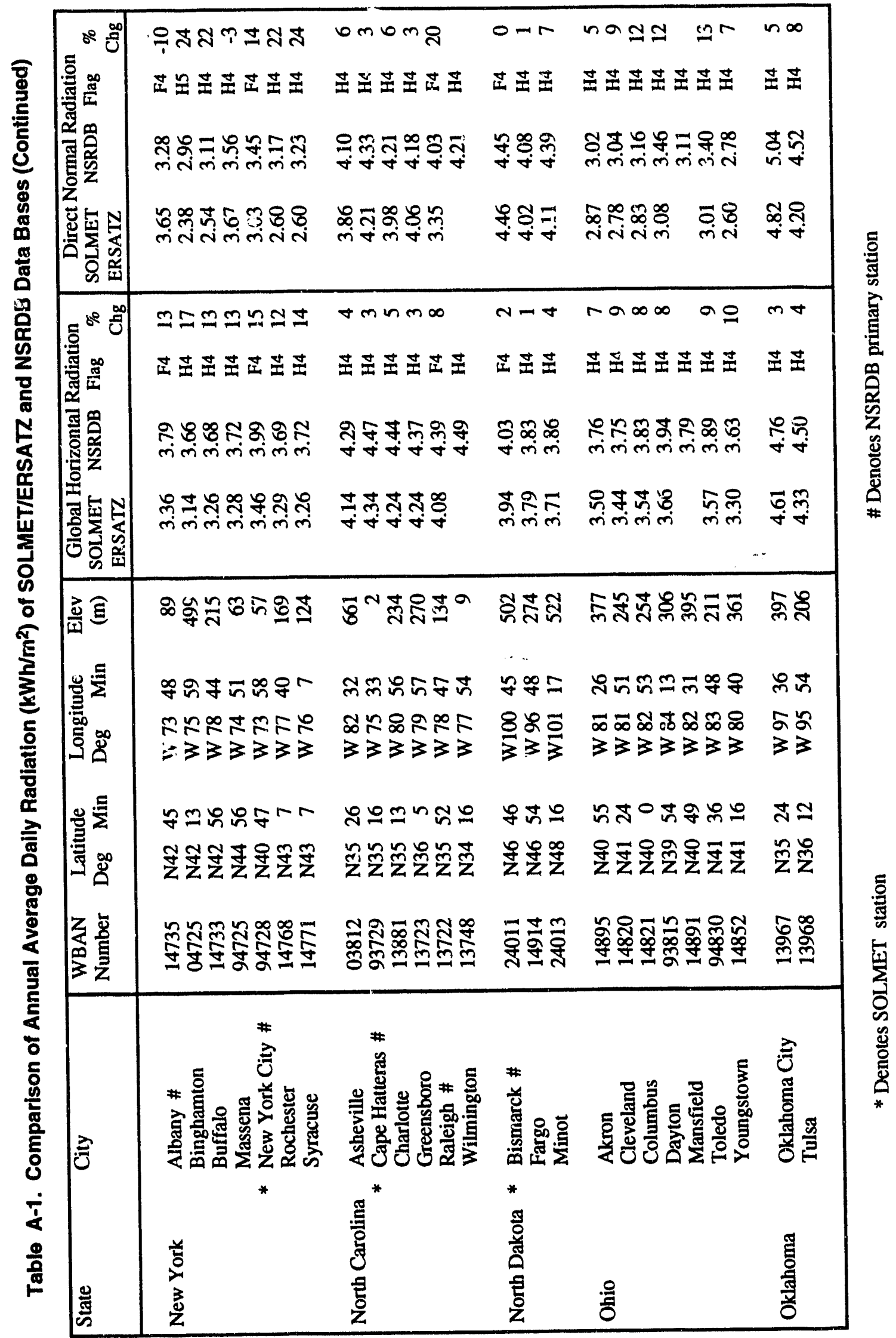




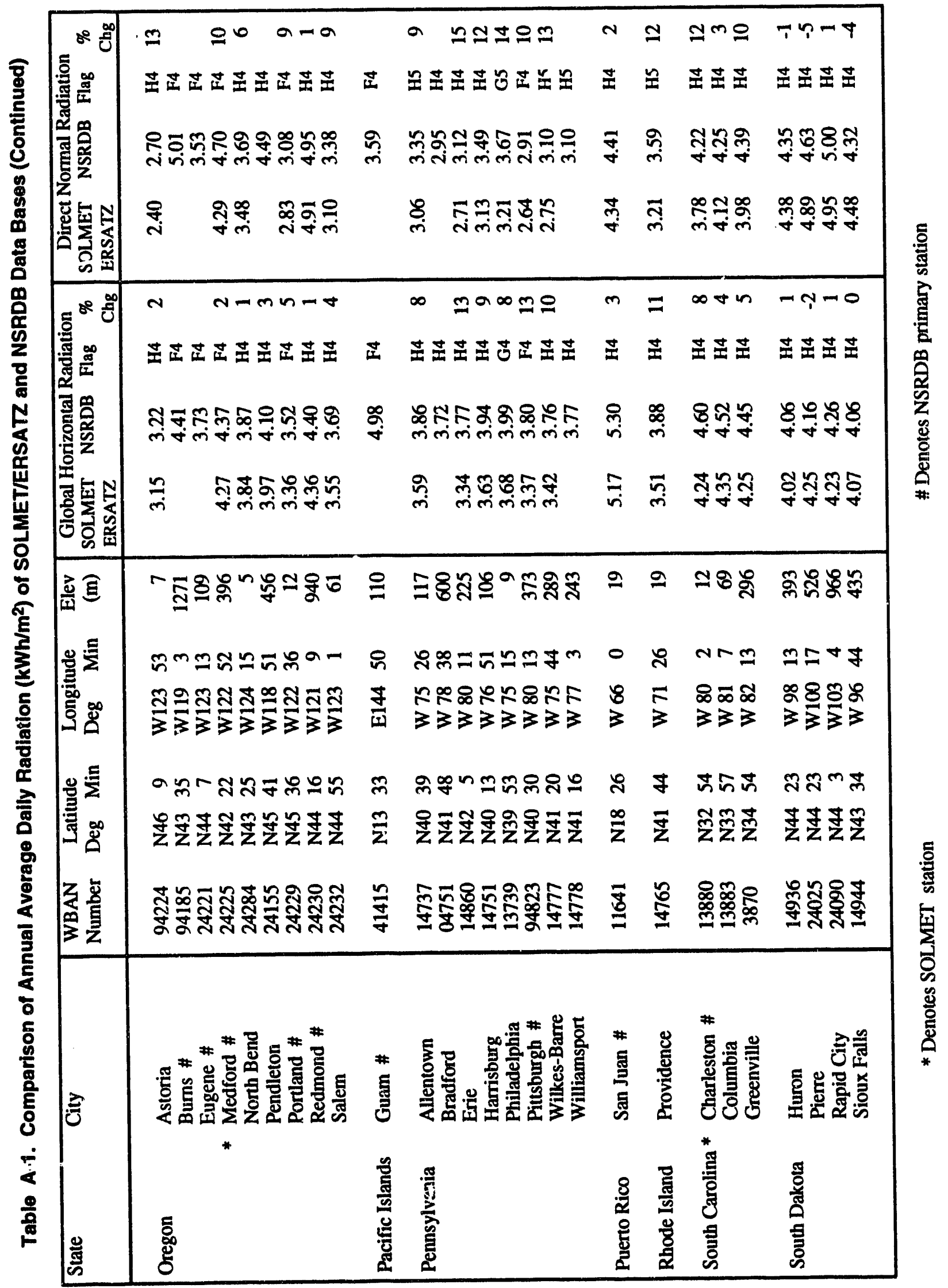




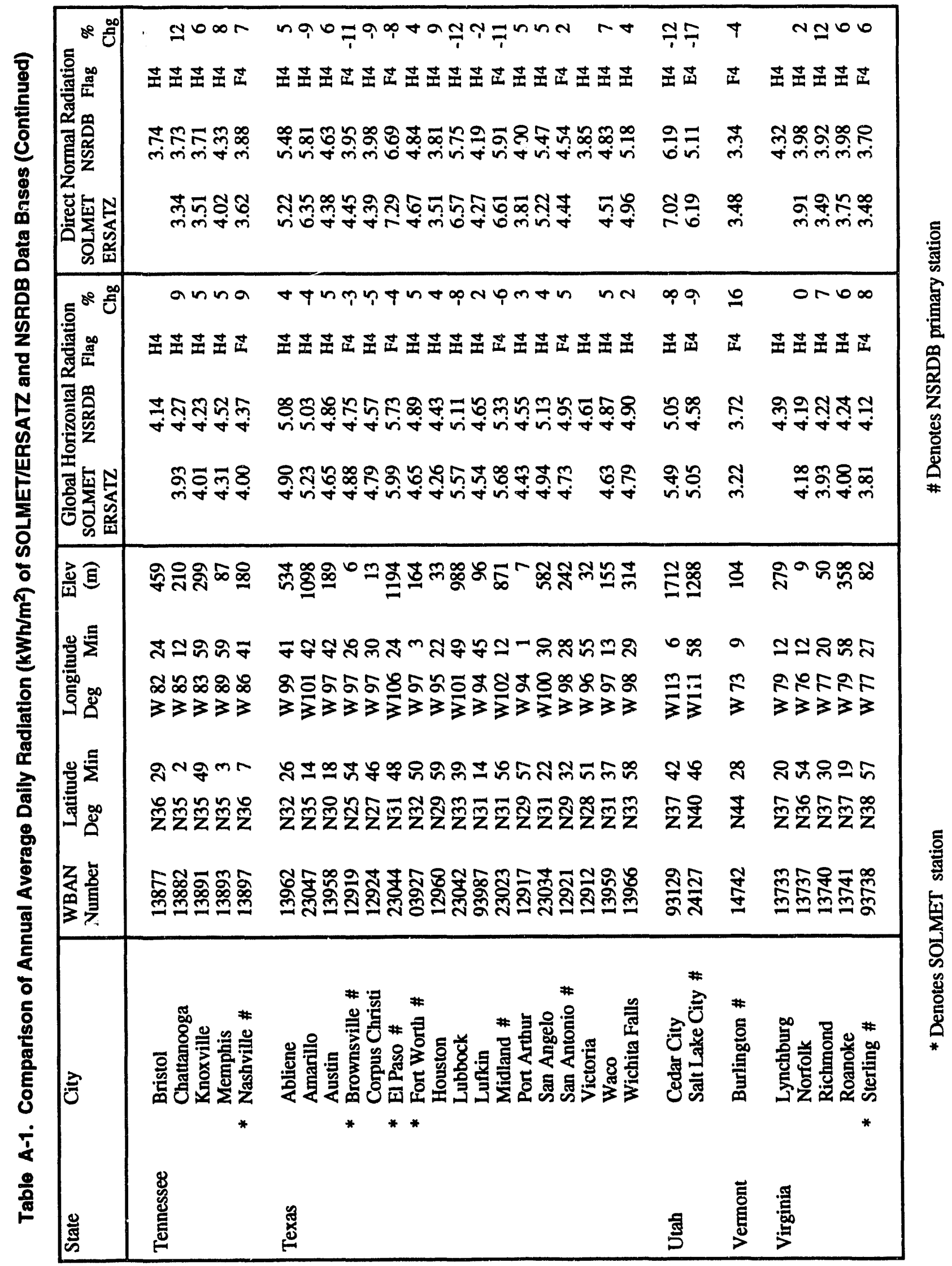




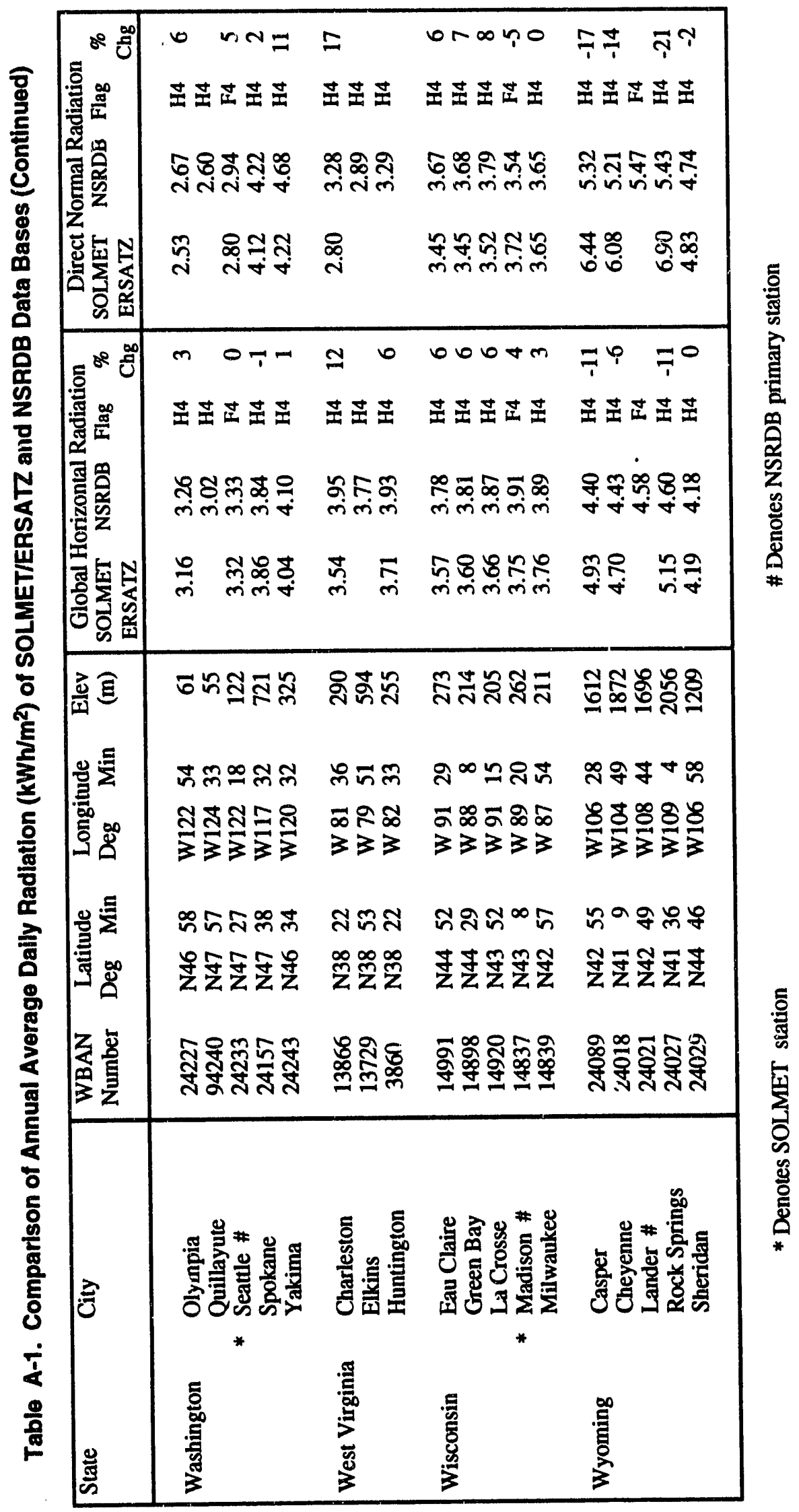




\section{Appendix B}

Comparison of Monthly Average Daily Radiation of SOLMET/ERSATZ and NSRDB Data Bases 


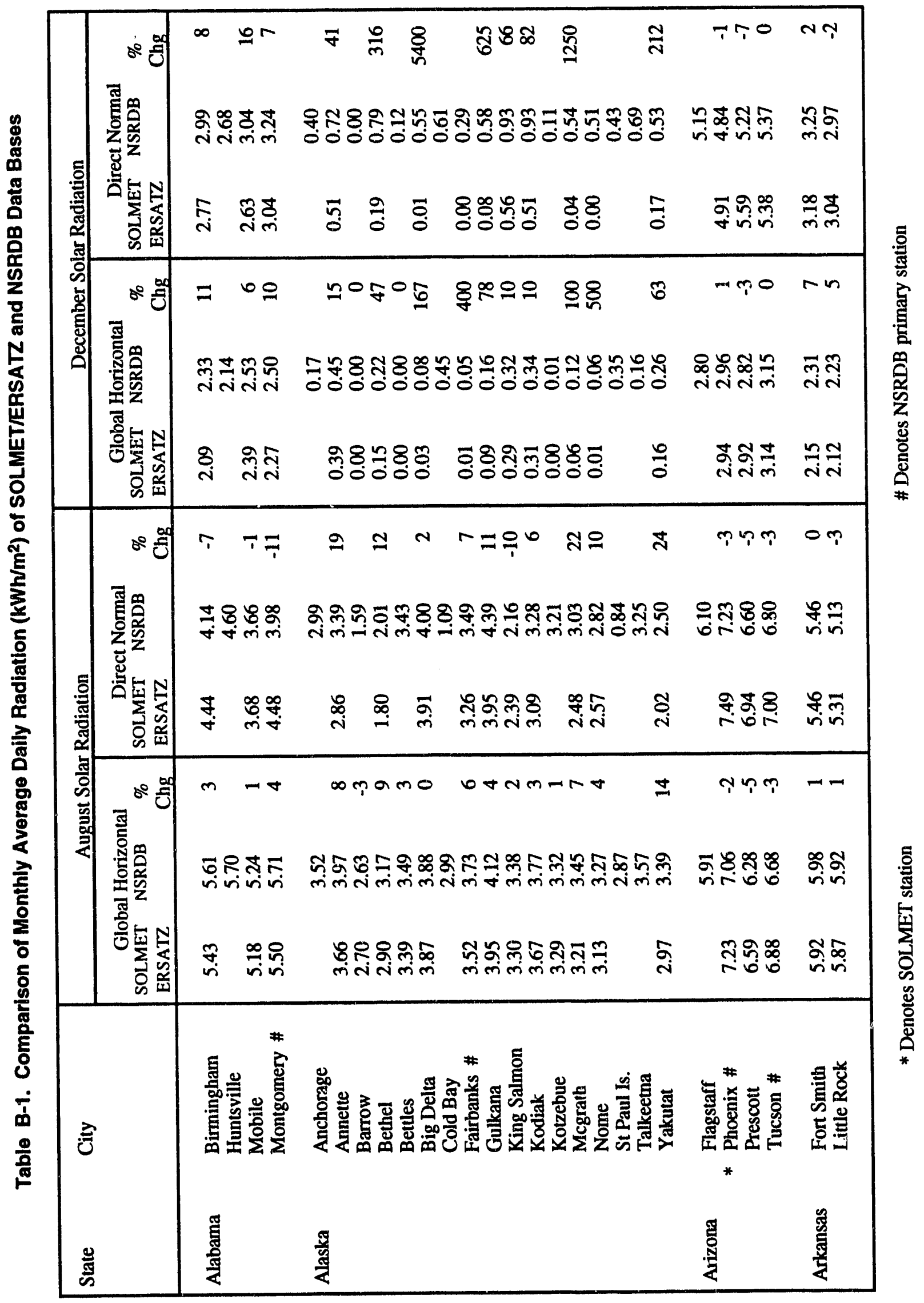




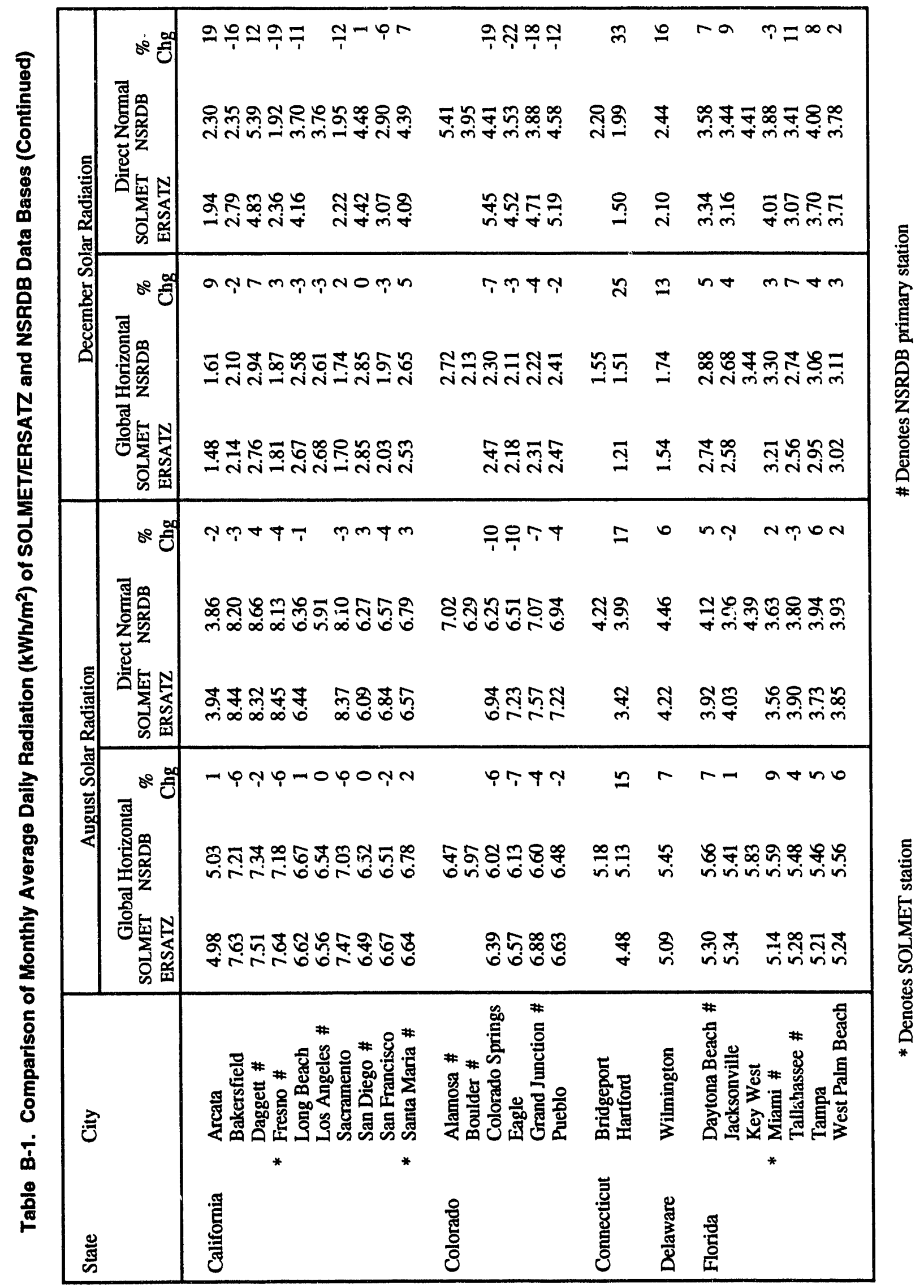




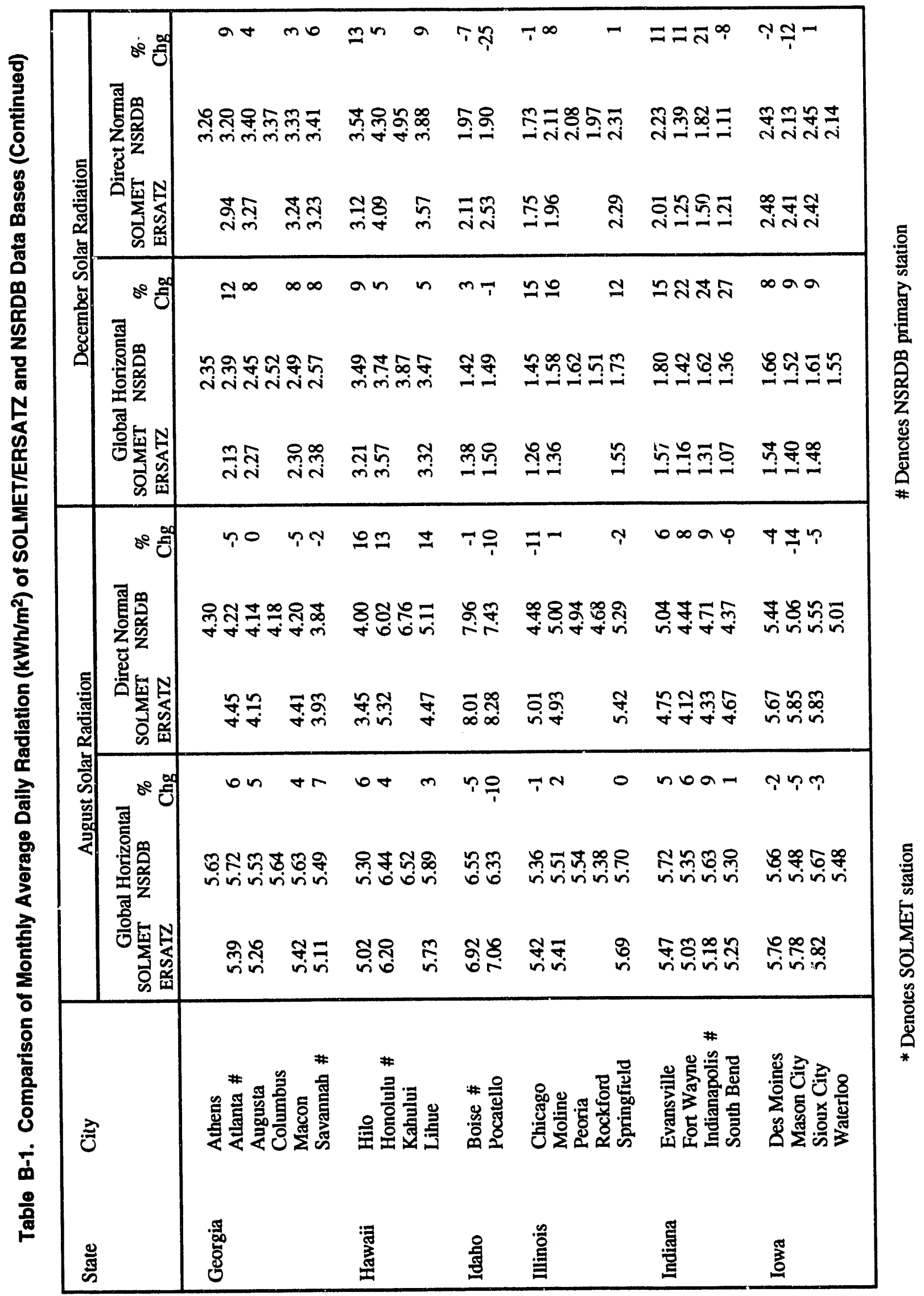




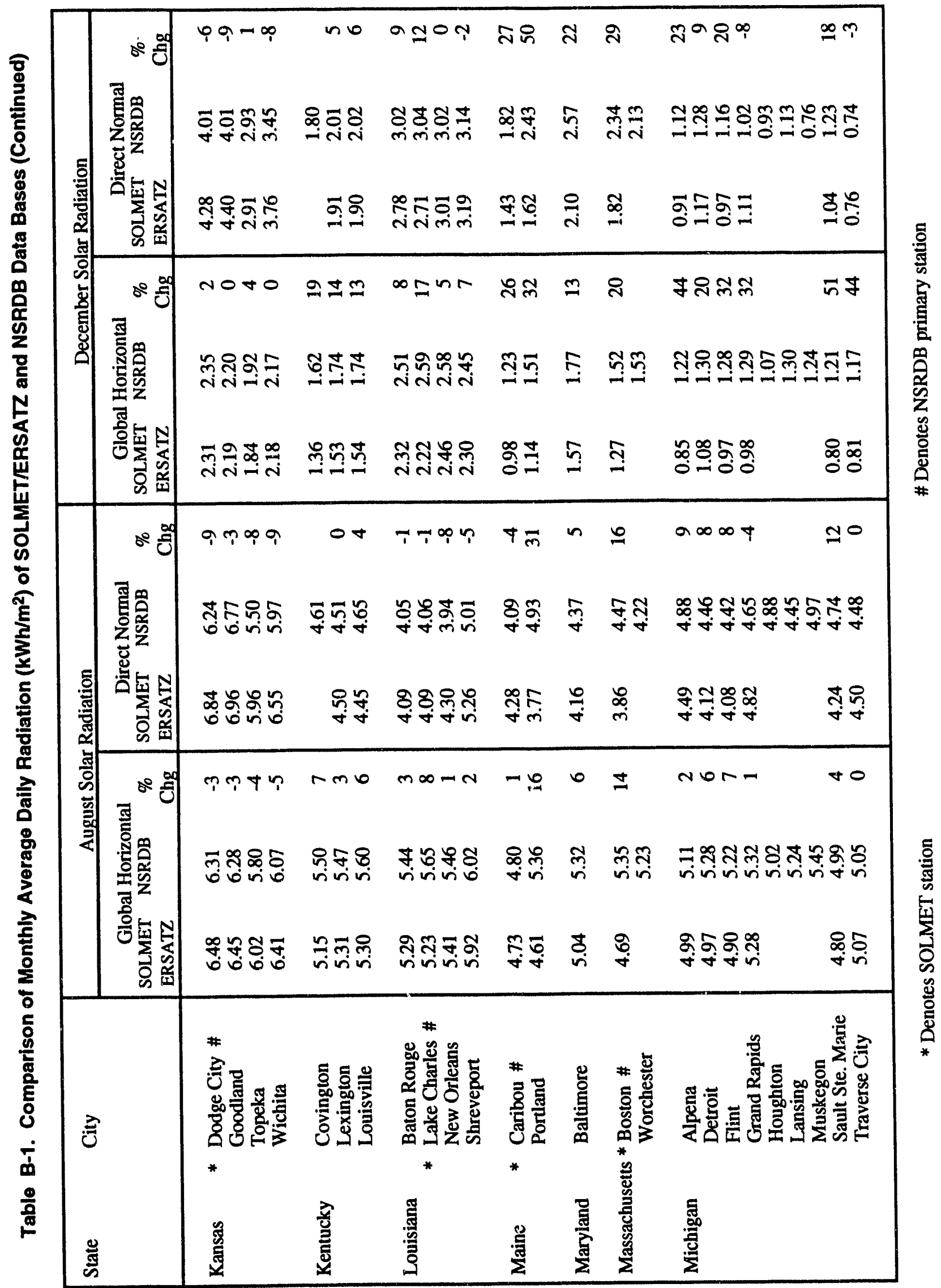




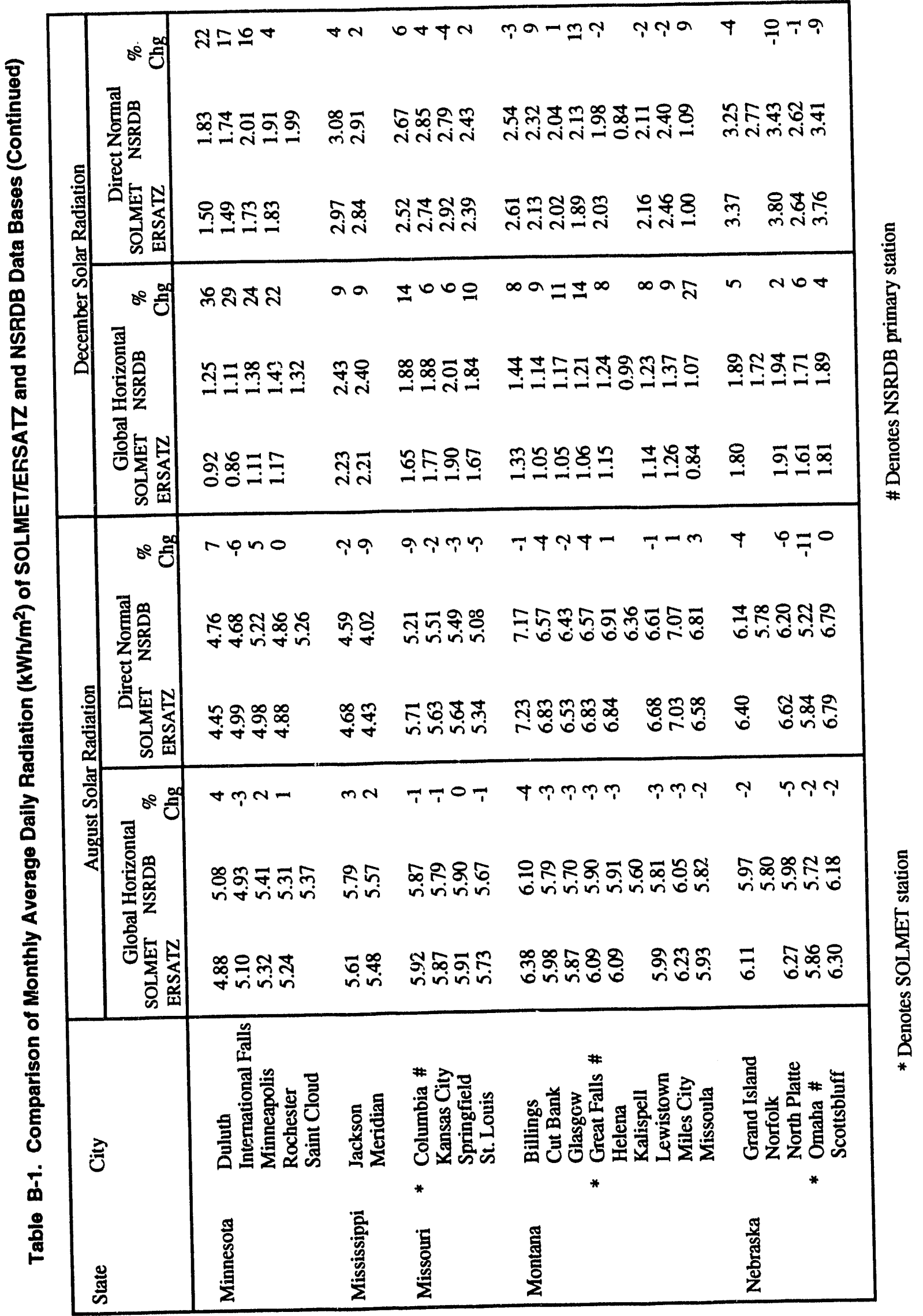




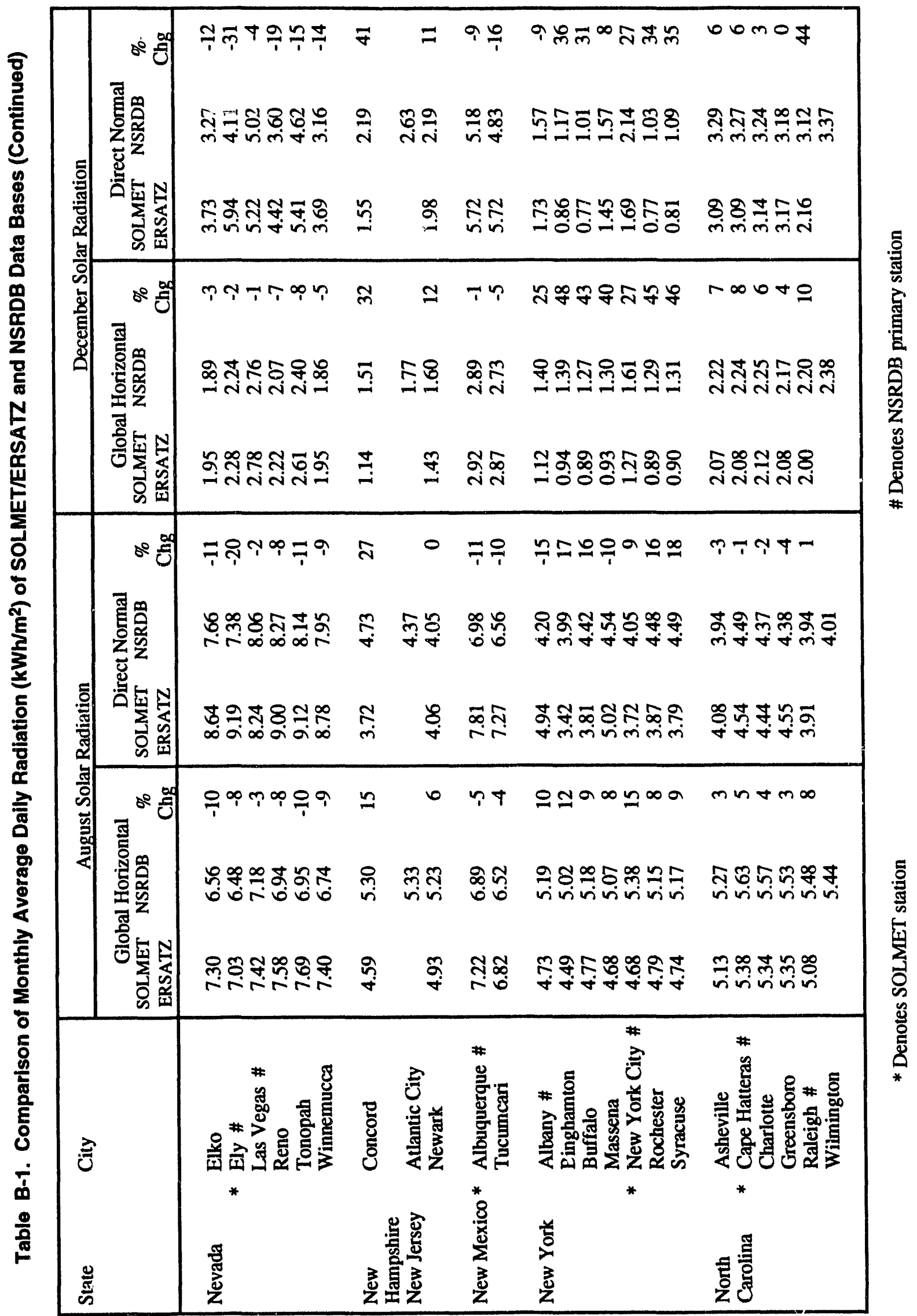




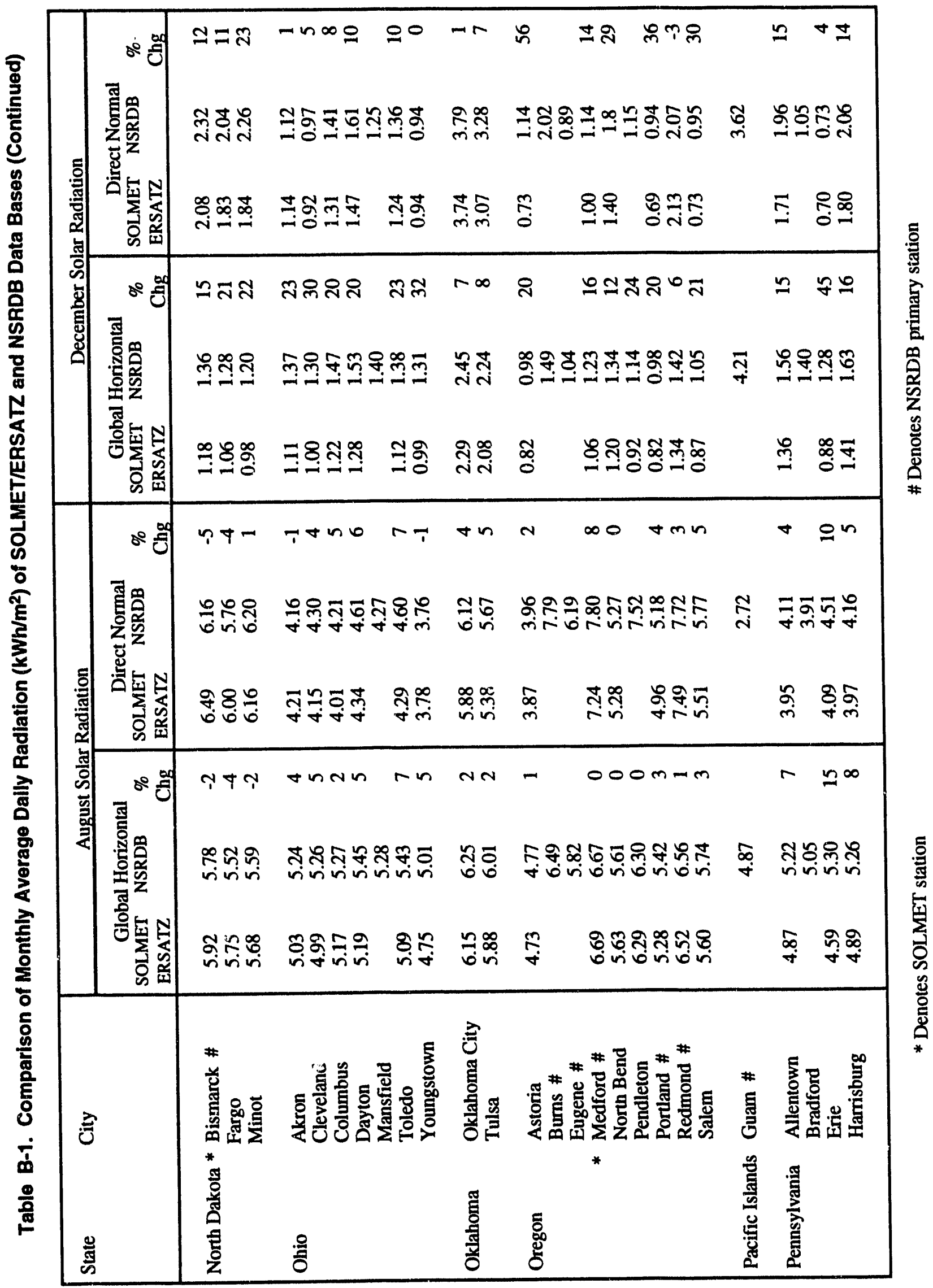




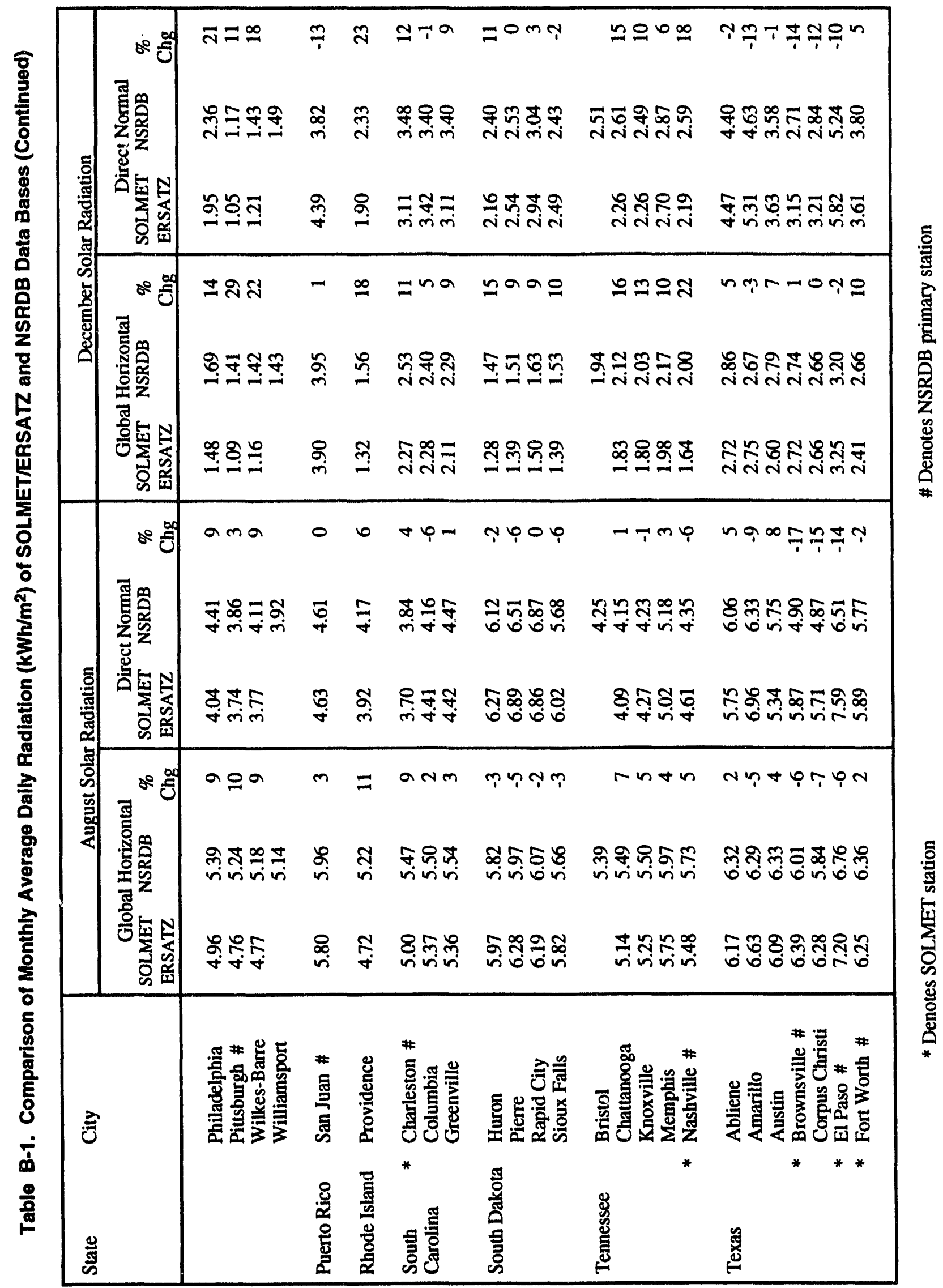




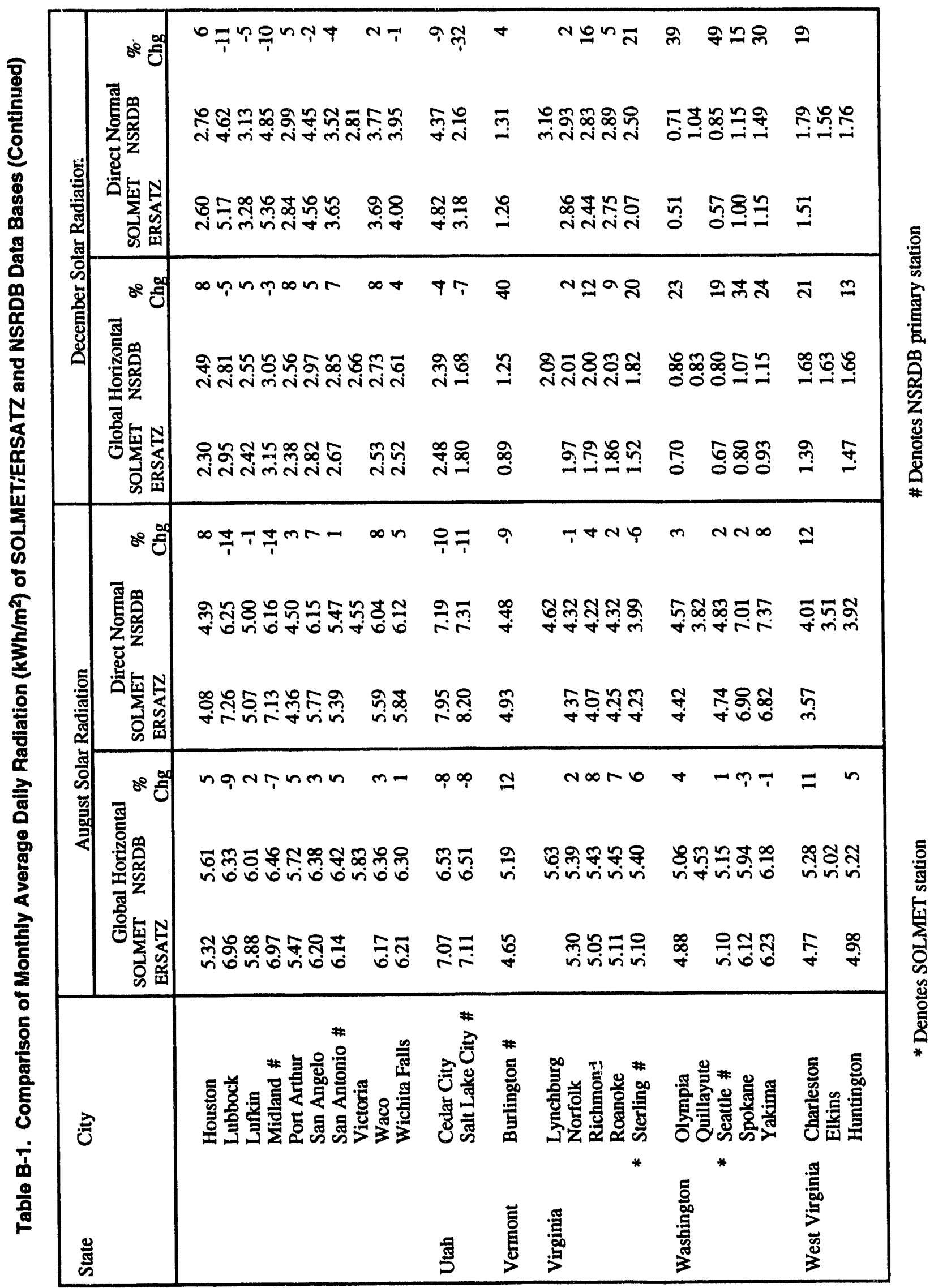




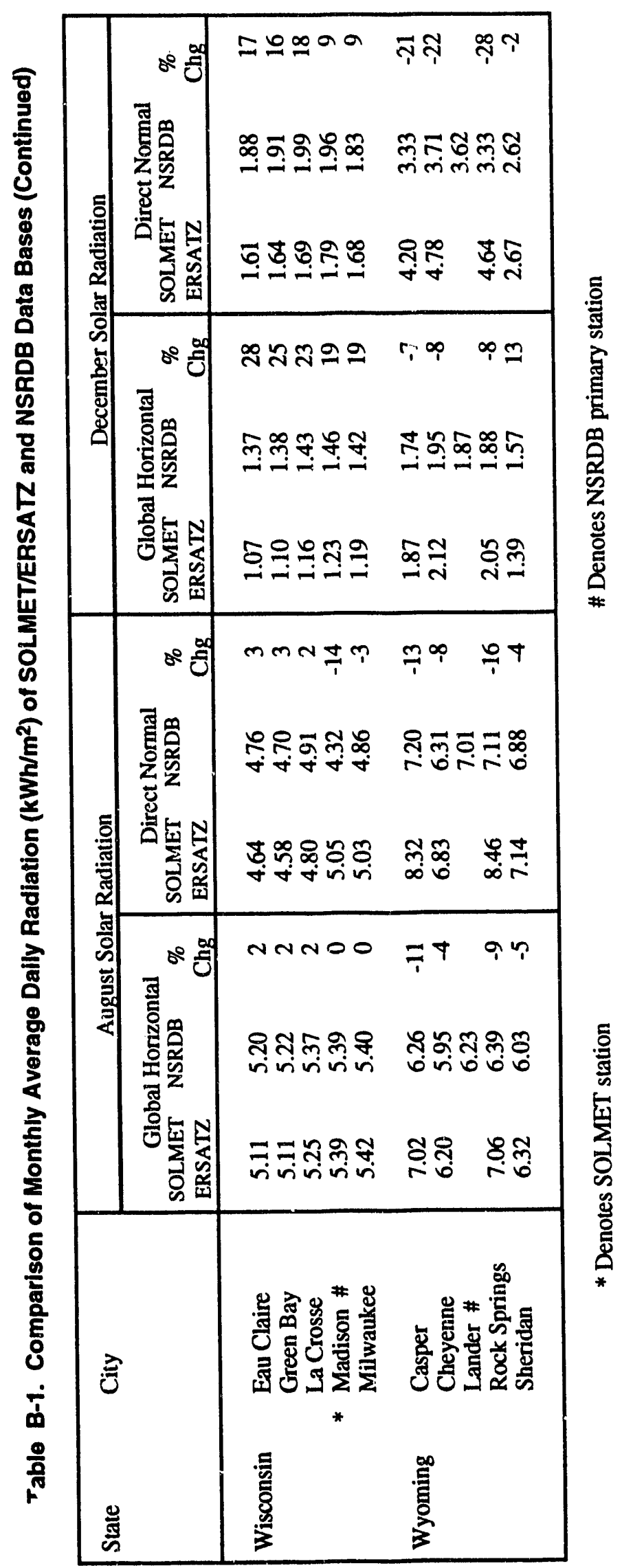



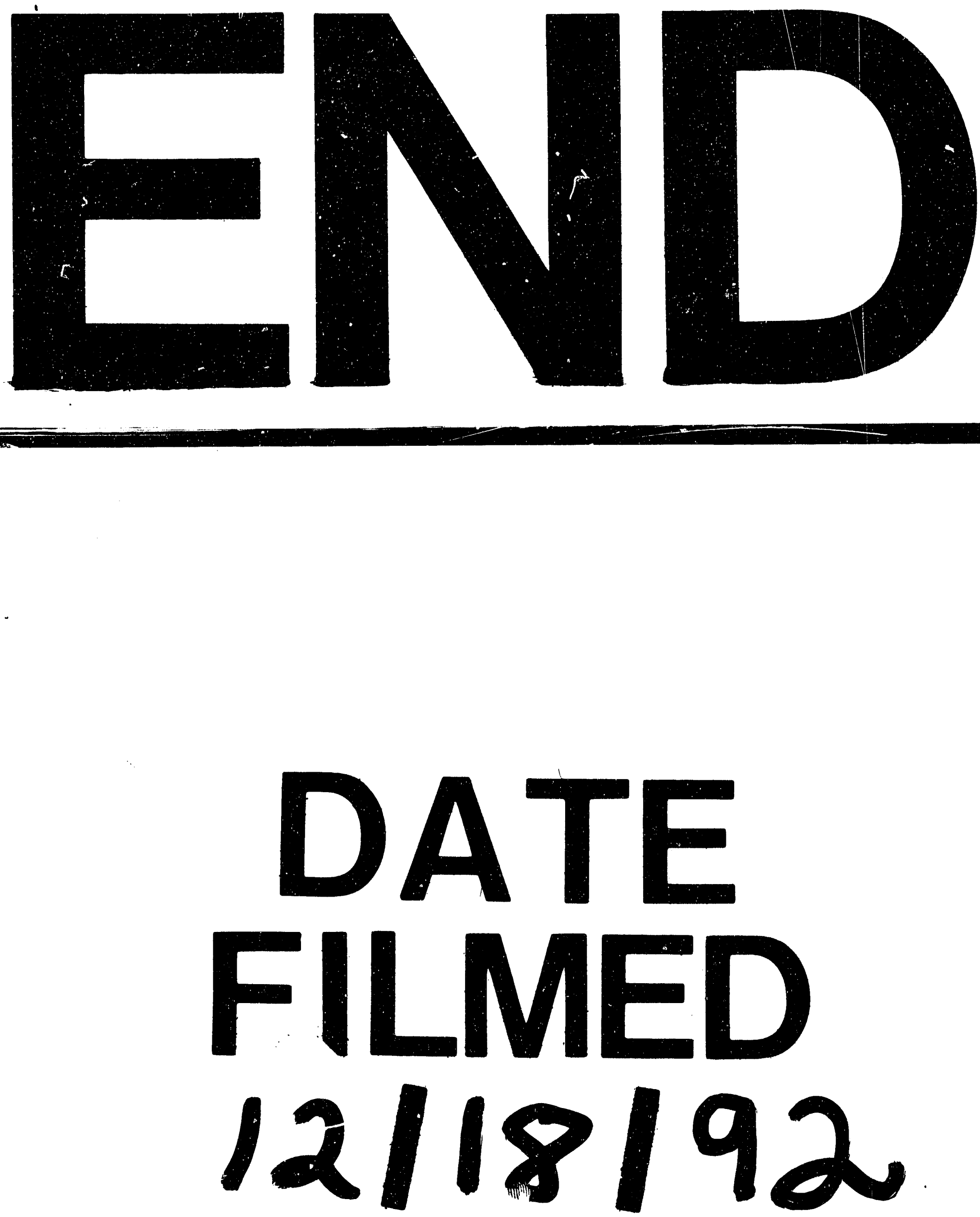
